\title{
Interactions of pathological proteins in neurodegenerative diseases
}

\author{
Tara L. Spires-Jones ${ }^{1}$ (i) $\cdot$ Johannes Attems $^{2} \cdot$ Dietmar Rudolf Thal $^{3,4}$
}

Received: 9 January 2017 / Revised: 30 March 2017 / Accepted: 1 April 2017 / Published online: 11 April 2017

(C) The Author(s) 2017. This article is an open access publication

\begin{abstract}
Neurodegenerative diseases such as Alzheimer's disease (AD), frontotemporal lobar degeneration (FTD), Lewy body disease (LBD), Parkinson's disease (PD), and amyotrophic lateral sclerosis (ALS) have in common that protein aggregates represent pathological hallmark lesions. Amyloid $\beta$-protein, $\tau$-protein, $\alpha$-synuclein, and TDP-43 are the most frequently aggregated proteins in these disorders. Although they are assumed to form disease-characteristic aggregates, such as amyloid plaques and neurofibrillary tangles in $\mathrm{AD}$ or Lewy bodies in LBD/PD, they are not restricted to these clinical presentations. They also occur in non-diseased individuals and can co-exist in the same brain without or with a clinical picture of a distinct dementing or movement disorder. In this review, we discuss the co-existence of these pathologies and potential additive effects in the human brain as well as related functional findings on cross-seeding and molecular interactions between these aggregates/proteins. We conclude that there is evidence for interactions at the molecular level as well as
\end{abstract}

Tara L. Spires-Jones, Johannes Attems and Dietmar Rudolf Thal contributed equally to this manuscript.

Tara L. Spires-Jones

tara.spires-jones@ed.ac.uk

1 Centre for Dementia Prevention, and Euan MacDonald Centre for Motor Neurone Disease, The University of Edinburgh Centre for Cognitive and Neural Systems, 1 George Square, Edinburgh EH8 9JZ, UK

2 Institute of Neuroscience, Newcastle University, Campus for Ageing and Vitality, Newcastle upon Tyne NE4 5PL, UK

3 Departement Neurowetenschappen, Katholieke Universiteit Leuven, Herestraat 49, 3000 Leuven, Belgium

4 Departement Pathologische Ontleedkunde, UZ Leuven, Herestraat 49, 3000 Leuven, Belgium for additive effects on brain damage by multiple pathologies occurring in different functionally important neurons. Based upon this information, we hypothesize a cascade of events that may explain general mechanisms in the development of neurodegenerative disorders: (1) distinct lesions are a prerequisite for the development of a distinct disease (e.g., primary age-related tauopathy for AD), (2) diseasespecific pathogenic events further trigger the development of a specific disease (e.g., $\mathrm{A} \beta$ aggregation in $\mathrm{AD}$ that exaggerate further $\mathrm{A} \beta$ and $\mathrm{AD}$-related $\tau$ pathology), (3) the symptomatic disease manifests, and (4) neurodegenerative co-pathologies may be either purely coincidental or (more likely) have influence on the disease development and/or its clinical presentation.

Keywords Alzheimer's disease · Amyotrophic lateral sclerosis · Frontotemporal lobar degeneration · Lewy body $\cdot$ Amyloid beta $\cdot$ Tau $\cdot$ Synuclein $\cdot$ TDP-43

\section{Introduction}

Neurodegenerative disorders are characterized by protein aggregates, the importance of which in inducing neuronal toxicity has been hotly debated. Pathological forms of proteins also appear to spread through the brain in characteristic patterns in most neurodegenerative diseases, with particularly robust evidence for the spread of amyloid beta (A $\beta)$, tau $(\tau)$, and $\alpha$-synuclein ( $\alpha$-syn) [43, 73]. Although each neurodegenerative disorder exhibits accumulation of specific characteristic protein aggregates, there are also many cases that exhibit aggregation of multiple pathological proteins. Studies in model systems including transgenic animals and cell culture support several potential types of interactions between different pathological proteins 
involved in neurodegeneration including cross-seeding of aggregates and pathological changes in one protein initiating mislocalization and post-translational modifications of another. Here, we will examine the neuropathological co-occurrence of pathologies in human autopsy cases and discuss potential mechanistic links between these diverse proteins in disease pathogenesis. We will focus on the pathological proteins for which there is the clearest evidence of both co-existence in human cases and biological evidence for potential mechanistic interactions. Table 1 summarizes the neurodegenerative diseases we will cover and the protein aggregates most commonly observed in the brains of people with those diagnoses. The co-occurrence of cerebrovascular pathology and protein aggregates is discussed in the other article of this cluster [77]. Here, our aim is to provide an updated view about the co-occurrence of different protein aggregates in neurodegeneration and their possible mutual interactions which should further our understanding of the biology of neurodegenerative disorders.

\section{$A \beta$ and $\tau$-interactions of the classic hallmarks of Alzheimer's disease (AD)}

$\mathrm{AD}$ is the most common dementing disorder seen in $50-60 \%$ of dementia cases. Neuropathologically, AD is characterized by dramatic atrophy of the gray matter and accumulation of amyloid plaques and neurofibrillary tangles (NFTs) [60]. Amyloid plaques consist of extracellular aggregates of $A \beta$ [93], which is a cleavage product derived from the amyloid precursor protein (APP) by $\beta$ - and $\gamma$-secretase cleavage [53]. The same $A \beta$ peptide also occurs in AD-related vascular deposits known as cerebral amyloid angiopathy (CAA) [7]. A $\beta$-plaques as well as vascular $\mathrm{A} \beta$ deposits first occur in neocortical areas and then expand into further brain regions in a distinct hierarchical sequence $[141,143]$.

\section{Age-related accumulation of $A \beta$ and $\tau$}

Age is the most important risk factor for Alzheimer's disease, and for most sporadic, non-inherited neurodegenerative disorders. However, the question of why age is associated with increased risk for neurodegeneration remains unclear. We have examined pathological cohorts at different ages to characterize pathological accumulations. $A \beta$ deposits are observed as early as 11-20 years of age, and their frequency and phase of distribution increases with increasing age. At 80 years of age, approx. $80 \%$ of all autopsy cases show $A \beta$ plaques (see also Fig. 1b), whereas approx. $20 \%$ do not develop any amyloid plaques up to the age of 100 years [15]. Symptomatic AD seen in the old age groups exhibits a prevalence ranging from $11 \%$ in the age group over 64 years to $32 \%$ in the age group over 84 years [3]. In parallel with the $\tau$ and $A \beta$ pathology, neuritic plaques also become more prevalent with aging. In the cohort of cases covered in Fig. 1c, they were first seen between 41-60 years of age and reached approximately 55\% prevalence in the age group of 81-100 years. Amyloid pathology alone is not sufficient to cause symptomatic Alzheimer's disease, and many non-demented people show early phases of plaque pathology with aging.

NFTs represent neuronal cytoplasmic aggregates of abnormal $\tau$-protein that form paired helical filaments [48]. The first step in the formation of these aggregates is the abnormal phosphorylation of the $\tau$-protein, the dissociation of $\tau$ from axonal microtubules, and its aberrant accumulation in the somatic cytoplasm and dendrites. Somatodendritic accumulations of phosphorylated $\tau$ before fibrils are formed and are called "pretangles" $[2,9]$. NFTs consisting of paired helical filaments of $\tau$ develop after (and presumably directly from) pretangles and correlate with neuronal degeneration. NFTs remain as ghost tangles even after the death of neurons, but the amount of neuronal death in AD exceeds the amount of NFT formation, indicating that NFTs are not necessary for cell death $[9,11,45]$. In the human brain, silver-stainable NFTs start to develop in the transentorhinal cortex and in a few subcortical brain stem nuclei (locus coeruleus, raphe nuclei, basal nucleus of Meynert) [13, 15]. From the transentorhinal cortex, NFT pathology spreads into the entorhinal region and then further into other brain regions in a distinct hierarchical sequence that is different from that for $A \beta$-plaques [12]. The $\tau$-protein occurs in the human brain in six isoforms, which have a characteristic microtubule-binding repeat region [44]. Three $\tau$ isoforms have 3 repeats in the repeat region, whereas the other three isoforms have 4 repeats. In $\mathrm{AD}$, both 3- and 4-repeat isoforms are detected in the $\tau$-aggregates [44].

As with $A \beta$, the prevalence of $\tau$ pathology increases with age but can be detected in surprisingly young people. The earliest signs of an abnormal accumulation/aggregation have been found in a 6-year-old boy [13] in the locus coeruleus (the brainstem nucleus that represents the noradrenergic center of the brain) exhibiting non-fibrillar abnormal phosphorylated $\tau$-protein. These first $\tau$-accumulations were pretangles. Pretangles were seen in other brainstem and subcortical nuclei, namely the raphe nuclei (serotonergic brain stem nuclei), and the basal nucleus of Meynert (cholinergic nuclei of the brain) at later ages. At 40 years of age, most human individuals showed brainstem $\tau$ pathology $[8$, 15]. The first NFTs consisting of paired helical filaments were seen in individuals between 10 and 20 years of age, but the question of whether these NFTs are already associated with $\mathrm{AD}$ or if they are unrelated to $\mathrm{AD}$ remains controversial $[15,28]$. However, with advancing age, NFT- $\tau$ 


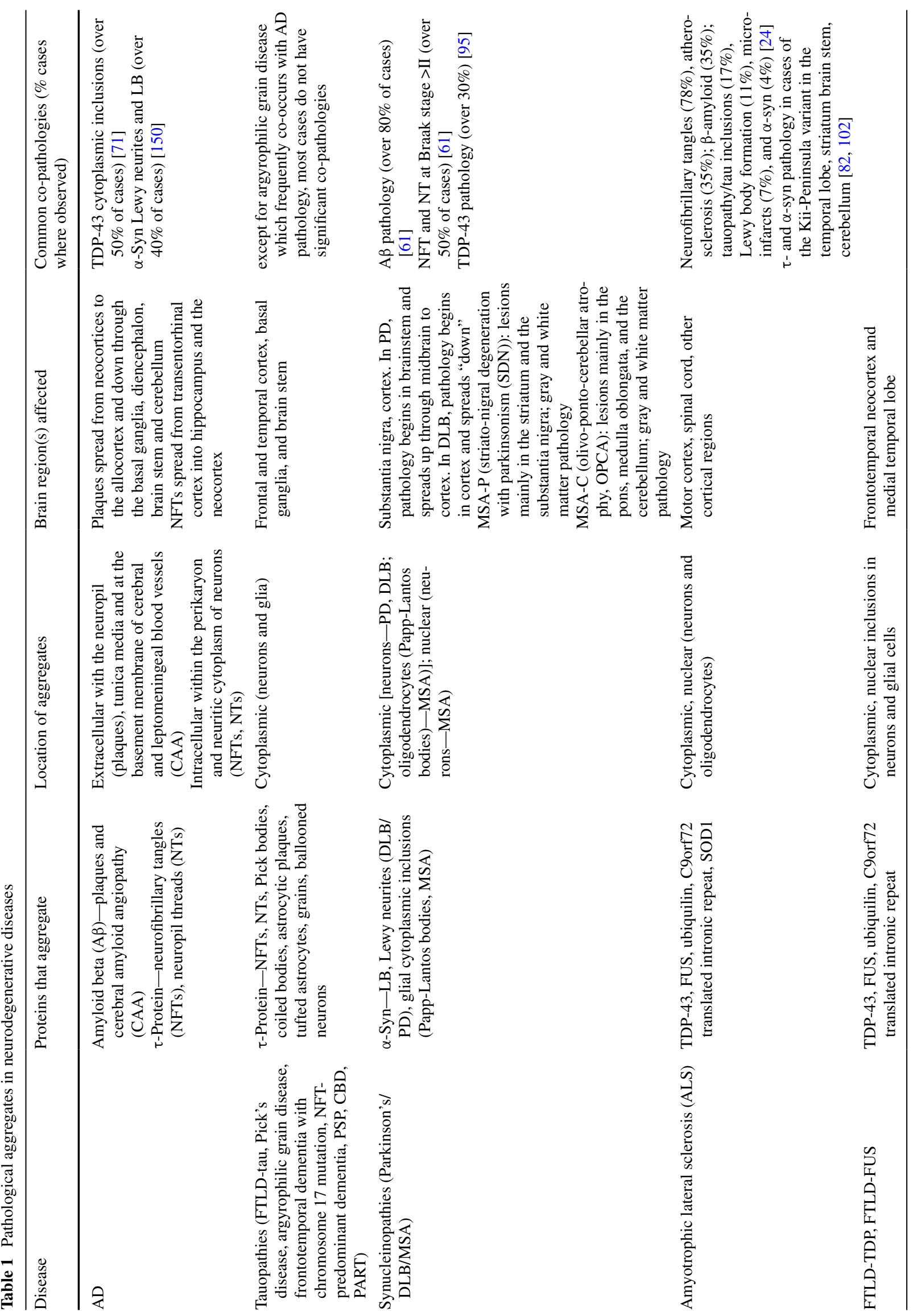




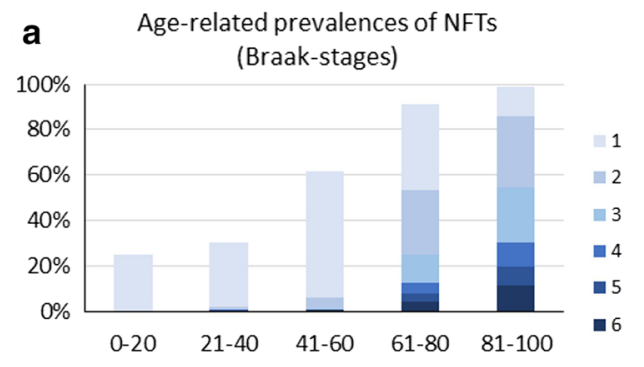

C Age-related prevalence of neuritic plaques (CERAD scores)

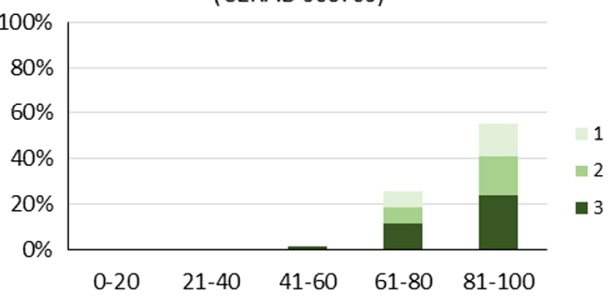

e Age-related prevalences of TDP-43 inclusions in

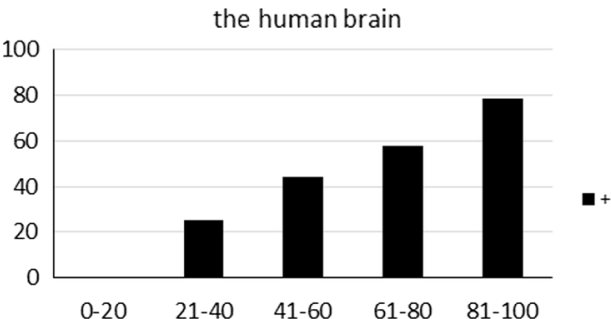

Fig. 1 Pathological proteins accumulate with increasing age as measured in large post-mortem studies. Age-related prevalence of NFTs (a, $n=1310), \mathrm{A} \beta$ plaques (b, $n=849)$, neuritic plaques (c, $n=662)$, AD pathology as defined by NIA-AA (d, $n=662)$, TDP-43 pathology $(\mathbf{e}, n=147)$, and Lewy body pathology (f, $n=582)$ (reevaluation of previously published cases by the authors (JA, DRT) [95, 139, $146,147])$. The prevalence for NFTs is provided separately for each Braak-NFT stage (I-VI) [12] (a) and that for A $\beta$ plaques separately for each phase of $\mathrm{A} \beta$-plaque deposition as determined in medial temporal lobe sections (1-4) [144] corresponding with the plaques extension all over the entire brain [143]. The frequency of neuritic plaques (c) is shown separately for each CERAD score (1-3) [98]. The neuritic plaques were detected in these cases by Gallyas silver staining

pathology becomes more prevalent and higher Braak-NFT stages also become more prevalent. In people over 91 years of age, nearly every individual shows at least Braak-NFT stage 1 [15] (see also Fig. 1a).

Neurofibrillary tangle pathology is not exclusively found in association with $\mathrm{A} \beta$ deposition as evidenced by the disease primary age-related tauopathy (PART). PART is characterized by the presence of neuronal $\tau$-protein pathology in the form of neurofibrillary tangles (NFT) and neuropil threads (NT) without (definite PART) or with only limited (possible PART) parenchymal amyloid- $\beta(\mathrm{A} \beta)$ depositions (up to phase 2 according to Thal et al. [143]) [28]. In addition, any other primary

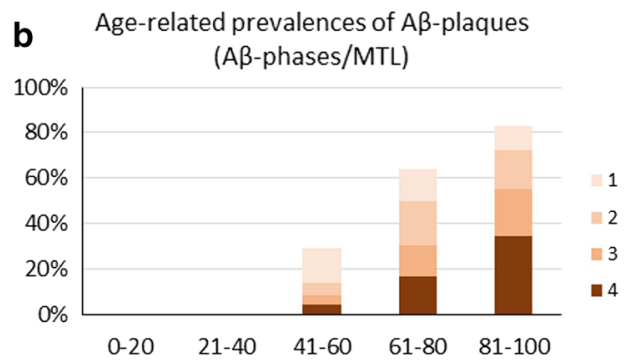

d Age-related prevalences of $A D$ pathology

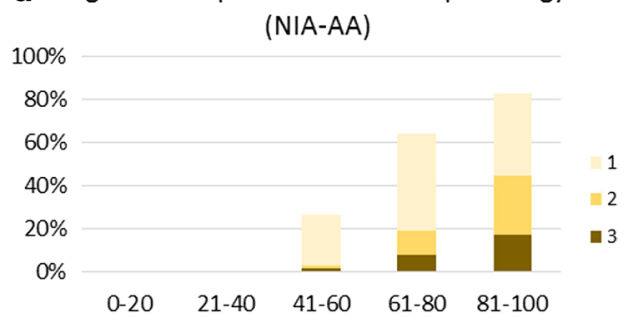

f Age-related prevalence of the stages of Lewy-

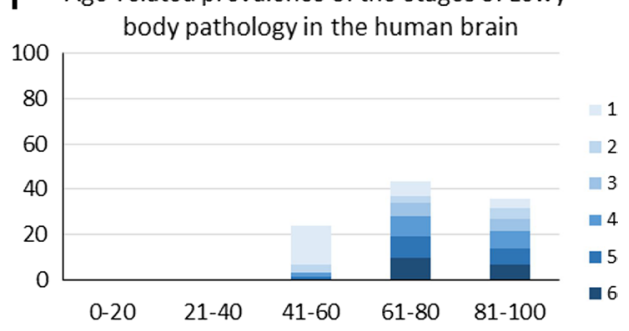

or immunohistochemistry against abnormal phosphorylated $\tau$-protein (AT-8) $[142,146]$. The degree of AD pathology has been assessed in accordance with the current neuropathological criteria for the description of AD pathology as published by the National Institute of Aging and the Alzheimer Association [low (1)—high (3)] [60] (d). The prevalence of TDP-43 aggregates was assessed dichotomously on the basis of an immunostaining with an antibody against phosphorylated TDP-43 (presence $=1)(\mathbf{e})$. The prevalence of LB pathology was assessed by classifying the LB pathology according to Braak et al. (1-6) [14]. Prevalences were provided separately for each stage (f). In contrast, to $\tau, A \beta$, and TDP-43 pathology, the prevalence of LB pathology decreases after a peek in the age group 61-80 years probably indicating a life expectancy limiting effect of LB pathology

tauopathy (such as PSP, CBD, and AGD, etc.) has to be excluded. PART is frequent in old age (up to $40 \%$ ) and is likely to represent the neuropathological correlate of a condition termed "suspected non-AD pathophysiology" (SNAP), which refers to individuals with temporal lobe atrophy on MRI and high CSF $\tau$ but no evidence for cerebral A $\beta$ depositions [64]. SNAP is usually seen in cognitively normal elderly but may also be present in mildly impaired individuals. While the neuroanatomical progression of NFT/NT in PART follows AD-associated NFT-Braak stages [28], the latter do not exceed stage IV in PART and NFT-Braak stages V/VI are indeed only seen in the presence of $A \beta$ pathology. 
As PART is a rather novel entity, little is known about the co-occurrence of PART and other neurodegenerative diseases. However, in the Newcastle Brain Tissue Resource (NBTR), $12 \%$ of LBD cases show additional PART and in $45 \%$ of PART cases, pathological lesions typically associated with other diseases were present (e.g., ALS, stroke, multiple system atrophy), while $55 \%$ of all PART cases showed no signs of neurological disease during life and no or only very mild age-associated pathologies at post-mortem examination in addition to PART.

\section{Mechanistic links between $\mathrm{A} \beta$ and $\tau$}

Despite the existence of "pure" or "primary" tauopathies, it is clear that $\mathrm{A} \beta$ and $\tau$ pathologies are related, at least in AD. The link between $A \beta$ and $\tau$ pathologies is clearly evidenced in their convergence in the AD brain as neuritic plaques, in which $A \beta$ aggregates are associated with dystrophic neurites, which most frequently exhibit neurofibrillary lesions consisting of aggregates of abnormal phosphorylated $\tau$-protein [32]. Here, intracellular $\tau$ in dystrophic neurites together with extracellular $A \beta$ constitute one single pathological lesion, i.e., the neuritic plaque, which is a conditio sine qua non for the neuropathological diagnosis of symptomatic $\mathrm{AD}$. Although plaque and tangle pathologies begin in different brain regions and show different progression pattern (Table 1; Fig. 1), a recent PET imaging study found some convergence zones of $A \beta$ and $\tau$ pathologies, particularly in the inferior-lateral temporal lobe, which hints at physical, perhaps network-distributed interactions of these pathologies in disease progression [123].

Further evidence strongly implicating a mechanistic link between $A \beta$ and $\tau$ is the genetics of familial AD (fAD), which clearly implicates changes in $\mathrm{A} \beta$ processing not only in plaque formation but also in causing $\tau$ pathology. fAD mutations have been found in the APP gene, which codes for the amyloid precursor protein (APP) that is cleaved to form $\mathrm{A} \beta$, and also in the presenilin 1 and 2 genes (PSEN1, PSEN2) [42, 120, 130, 131], which form parts of the $\gamma$-secretase enzyme responsible for one of the essential proteolytic cleavages of APP to form A $\beta$ [161]. Pathogenic mutations in these genes lead to an increased production of $\mathrm{A} \beta$ and to the development of $\mathrm{AD}$. Neuropathologically, these cases show $\mathrm{A} \beta$ and $\tau$ aggregates similar to those observed in sporadic AD cases. In further support of $\mathrm{A} \beta$ generation being key to initiating $\mathrm{AD}$, other mutations in the APP gene that preclude $A \beta$ production have been shown to be protective [69]. Conversely, mutations in the MAPT gene encoding $\tau$ do not cause fAD, but can lead to neurodegenerative tauopathies which often include Parkinsonian symptoms [59]. Here, $\tau$ pathology occurs in neurons, astrocytes, and oligodendrocytes in a FTLD-tau-like pattern, sometimes producing Pick bodies. Co-occurrence of other neurodegenerative features except for age-related amounts are uncommon. The pattern in FTLD-tau cases with $\tau$-mutations is very variable [40]. The MAPT gene occurs on a part of chromosome 17 that has two major haplotypes called $\mathrm{H} 1$ and $\mathrm{H} 2$ due to an ancient inversion of a $900 \mathrm{~kb}$ region [132], and these haplotypes have been linked to the risk of several diseases. $\mathrm{H} 1$ haplotype is associated with increased risk of the tauopathies progressive supranuclear palsy (PSP) and corticobasal degeneration (CBD) and more recently to the risk of developing late-onset $\mathrm{AD}$ (LOAD) in people who do not carry the well-established LOAD risk gene APOE4 [110]. A relatively recently discovered mutation in $M A P T$, A152T, was discovered in a PSP patient and was subsequently found to be associated with increased risk of FTD, PSP, CBD, and AD [27].

Along with the co-occurrence of $\mathrm{A} \beta$ and $\tau$ pathologies in $\mathrm{AD}$ brain, and the human genetic data strongly suggesting that increased production of $\mathrm{A} \beta$ may trigger $\tau$ pathology, data in model systems also support a series of complex interactions between $\mathrm{A} \beta$ and $\tau$. Mouse models have been developed, which exhibit plaques due to overexpression of fAD-associated mutant proteins and $\tau$ pathology due to overexpression of FTD-associated mutant $\tau$. Generally, the results of these studies support the role of $A \beta$ in exacerbating $\tau$ pathology. For example, crossing Tg2576 mice which develop A $\beta$ pathology and JNPL3 tauopathy mice exacerbated the $\tau$ pathology [87]. In the 3xTg mice, which similarly have both $A \beta$ and $\tau$ pathology, lowering $A \beta$ levels causes a reduction in $\tau$ pathology, but conversely lowering $\tau$ levels does not reduce $A \beta$ pathology [108, 157], again arguing that $A \beta$ is upstream of $\tau$ pathology. In further support of this idea, mice that expresses human oligomeric $A \beta$ and human $\tau$ eventually develop NFT pathology even in the absence of tauopathy-associated mutations in the MAPT gene [152]. Moreover, in cell culture experiments, applying exogenous $A \beta$ to mouse primary neurons instigates $\tau$ phosphorylation and mislocalization to dendrites [163], and in human stem cell-derived neuronal cultures, overexpressing fAD mutations in APP and PS1 causes both plaque and tangle pathology [21]. Most of the evidence from genetics, mouse models, and cells indicates that $\mathrm{A} \beta$ drives $\tau$ pathology, but there are examples of surprising reciprocal interactions. For example, in the APP/PS1 mouse model, plaques are significantly larger in mice expressing either human P301L mutant [114] or wild-type human $\tau$ [65]. Not only does $A \beta$ appear to somehow instigate $\tau$ pathology, it may also gate the spread of $\tau$ pathology through the brain. A recent cross-sectional PET study examining both $A \beta$ and $\tau$ indicates this potential effect with hints that $A \beta$ pathology is necessary to start the spread of $\tau$ pathology out of the medial temporal lobe [123]. These imaging data accurately reflect neuropathological findings as $\tau$ pathology in the absences of $\mathrm{A} \beta$ (i.e., PART) does not exceed NFT-Braak 
stage IV, while NFT-Braak stages V/VI are only seen in the presence of $\mathrm{A} \beta$ further indicating an aggravating effect of $\mathrm{A} \beta$ on $\tau$ pathology. Similar to findings in the human brain, in rTgTauEC mice expressing FTD mutant $\tau$ restricted to the entorhinal cortex, the presence of plaques (generated by crossing the rTgTauEC line with APP/PS1 mice) accelerates the spread of $\tau$ through neural circuits [114]. However, while $A \beta$ may aggravate $\tau$ pathology, it is not a prerequisite for the mere development of $\tau$ pathology and hence $\mathrm{A} \beta$ must not be regarded as a mandatory upstream event in the development of $\tau$ pathology. The existence of non-AD tauopathies such as PSP, Pick's disease, and CBD strongly support the point of view that $A \beta$ is not required to develop a tauopathy that cases neurological/psychiatric symptoms.

While pathological lesions of $A \beta$ are mainly extracellular and $\tau$ lesions are intracellular, there are places in the brain where the soluble forms of these proteins, which are now thought to be the more toxic, bioactive species, may interact. One such important point of convergence is the synapse. Several factors indicate that synapses are key players in AD pathogenesis: (1) synapse dysfunction and loss occur early in the disease process (2) synapse loss is the strongest pathological correlate of cognitive decline, and (3) synaptic connections appear to be the point of spread of pathological proteins through neural circuits. A large body of literature shows that pathological soluble forms of $A \beta$ and $\tau$ can separately induce synaptic dysfunction and synapse loss, and more recently, evidence has begun to accumulate linking $\mathrm{A} \beta$ and $\tau$ in synapse degeneration [128]. Removing endogenous mouse $\tau$ protects mice against some $A \beta$-mediated
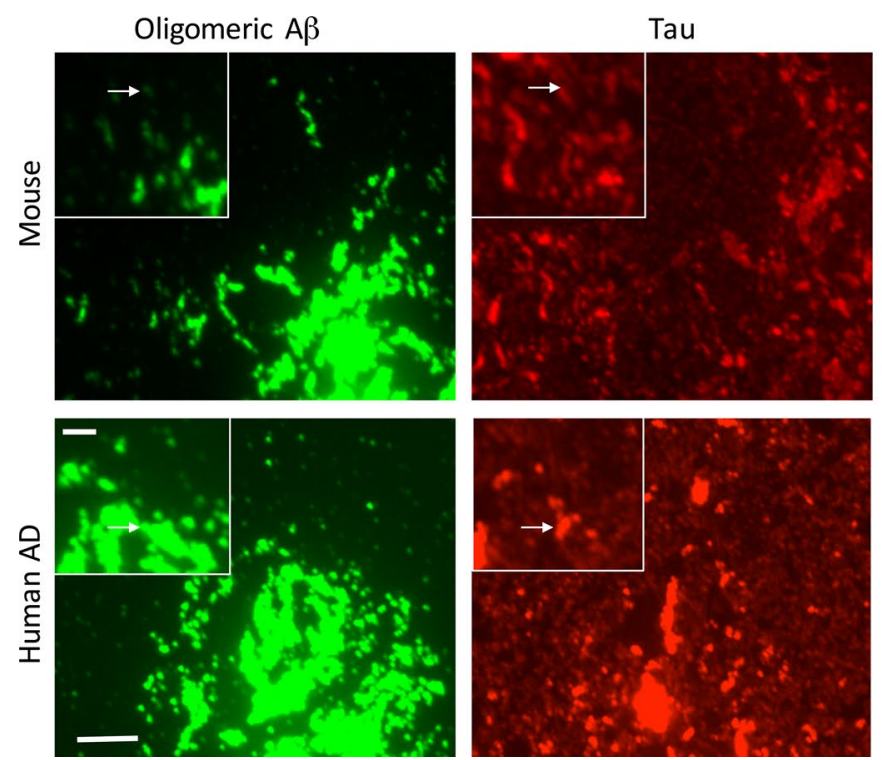

Fig. 2 Co-aggregation of pathological proteins in synapses may contribute to neurodegeneration. Synaptic toxicity of pathological proteins is thought to be one of the driving forces in several neurodegenerative diseases. In both a mouse model expressing fAD mutations in synaptic phenotypes such as seizure activity, synaptotoxicity, and long-term potentiation deficits [63, 119, 124], and the synapse loss observed with exogenous $A \beta$ application to cultured neurons is associated with local accumulations of phosphorylated $\tau$ in dendrites [163]. $A \beta$ and $\tau$ were also shown with immuno-electron microscopy to co-accumulate in postsynaptic terminals in 3xTg AD mice [136], although due to the limitations of electron microscopy, this was in a limited number of animals and was not quantified. We are using the array tomography technique to allow higher throughput quantitative imaging of synapses than EM and to overcome the $z$-resolution limit of light microscopy and accurately study the colocalization of pathological proteins of synapses in mouse and human brain with immunofluorescence $[78,97]$. These studies indicate that these proteins do co-occur in a subset of synapses in both mouse and human brain (Fig. 2). Our recent work in a novel mouse model indicates that there is not a strict dose-response relationship in the interactions of $A \beta$ and $\tau$ in synapse loss as addition of wild-type human $\tau$ in APP/PS1 mice with plaque-associated synapse loss does not exacerbate synapse loss [65]. Future work with temporal control over $\tau$ reduction in these plaque-bearing mice will determine whether $\tau$ is necessary for $\mathrm{A} \beta$-mediated synaptic phenotypes. Another potential mechanistic interaction at the synapse between proteins involved in different diseases is the role of cellular prion protein $(\mathrm{PrPc})$ in $\mathrm{A} \beta$-mediated synapse degeneration. PrPc becomes misfolded, aggregated, and toxic in Prion diseases such as variant Creutzfeldt-Jakob disease. In addition, PrPc has been proposed as a co-receptor with mGluR5

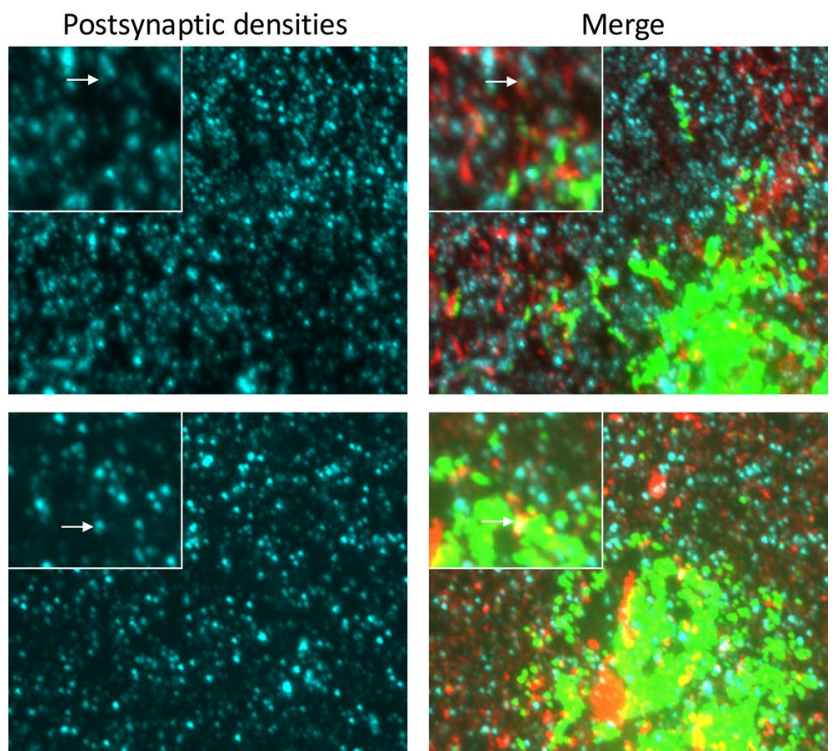

APP and PS1 and human wild-type $\tau$ ([65], top) and human AD brain (bottom), we observe colocalization of $\mathrm{A} \beta$ and $\tau$ at some synapses using the array tomography technique (arrows). Scale bars represent $5 \mu \mathrm{m}$ in large panel and $2 \mu \mathrm{m}$ in inset 
for oligomeric $\mathrm{A} \beta$ at synapses where it activates Fyn kinase and causes impaired synaptic plasticity [57, 85, 151]. This is a potentially very interesting cascade in light of the role of Fyn kinase in mediating $\tau$ toxicity at synapses, thus linking three pathological proteins in the same synaptotoxic cascade, at least in mouse models.

\section{Overlap of $\alpha$-syn with other pathologies}

Synucleinopathies encompass Lewy body diseases (LBD) and multiple system atrophy (MSA). The latter are characterized by glial $\alpha$-syn aggregations in the form of glial cytoplasmic inclusions (Papp-Lantos bodies) while the neuropathological hallmark lesions of LBD are $\alpha$-syn aggregates in neuronal cell somata and neuronal cell processes termed Lewy bodies (LB) and Lewy neurites (LN), respectively. LBD encompass Parkinson's disease (PD), Parkinson's disease dementia (PDD), and dementia with LB (DLB). While $\mathrm{PD}$ is primarily a movement disorder clinically characterized by the presence of extrapyramidal symptoms (EPS), clinical core features of PDD and DLB include fluctuating cognition and visual hallucinations [96]. There are no neuropathological criteria that allow to distinguish between PDD and DLB as this distinction can only be made based on clinical grounds; in PDD, EPS precede the onset of dementia by at least 12 months, whereas in DLB dementia is concomitant with or precedes EPS [96].

There are several neuropathological staging systems for LBD, the most frequently used are the Braak LBD stages and the Newcastle/McKeith criteria for LBD. Briefly, Braak LBD stages [14] postulate that nuclei in the medulla oblongata become initially affected (stage 1) and pathology spreads gradually to pons (stage 2), midbrain (stage 3 ), entorhinal cortex, and hippocampus (stage 4) and finally reaches the neocortex (stages 5 and 6). This topographical progression is not proposed in the Newcastle/McKeith criteria [96], which distinguish between brainstem predominant (PD), limbic (transitional; DLB), and diffuse neocortical (DLB) types of LBD. $\alpha$-Syn aggregates in the form of LB do not show a continuous increase with increasing age. Instead, the degree and prevalence of Lewy body pathology started in the 41- to 60-year-old age group and then increased up 61-80 years of age. In older individuals, the prevalence of the lesions at the different stages decreased (Fig. 1f). This decrease of Lewy body pathology is unexpected and could be explained by a reduced life expectancy of Lewy body pathology patients compared with that of AD patients. However, confirmation in independent samples and further, more detailed studies are required to clarify these findings.

While the neuropathological hallmark lesions of LBDs are LB/LN other pathologies are highly prevalent in LBDs;
$\mathrm{A} \beta$ depositions are present in up to $85 \%$ of LBD cases with dementia [61, 66, 76] and it has been suggested that striatal $\mathrm{A} \beta$ pathology is less frequent in PDD as compared to DLB (e.g., 18 vs. $100 \%$ in [76]), while in PD, A $\beta$ pathology is in general less frequent (e.g., 55\% in [66]) than in LBD with dementia. Similarly, $\tau$ pathology is frequently present in LBD [26, 66, 76] and a recently published study on 213 LBD cases with dementia found that $30 \%$ showed high Braak NFT stages V/VI [61]. Such cases which show neocortical LBD (i.e., DLB) and full-blown AD (i.e., Braak NFT stages V/VI) can be neuropathologically diagnosed as having mixed dementia (mixed AD/DLB), since the severity of either AD or LB pathology alone would be sufficient to represent a robust neuropathological correlate for clinical dementia. This raises the question as to why those cases clinically either present as DLB or AD. Using quantitative assessment of $\mathrm{A} \beta, \tau$-protein, and $\alpha$-syn in such mixed $\mathrm{AD} /$ DLB we found that those who clinically presented with AD had higher $\tau$ loads than those with clinical LBD [156]. Moreover, the hierarchical distribution of $\tau$-protein loads in clinical AD cases was similar to neuropathologically pure AD cases, while clinical DLB cases showed comparatively less hippocampal and temporal $\tau$ loads. These findings suggest that in clinical $\mathrm{AD}$ cases neuropathologically diagnosed as mixed AD/DLB neurodegeneration may be primarily driven by $\mathrm{AD}$ while $\mathrm{LB}$ pathology occurs later in the disease, possibly aggravated or even triggered by AD pathology. Conversely, in clinically diagnosed DLB cases, which show mixed AD/DLB at post-mortem examination, classical LB pathology (i.e., $\alpha$-syn) may be the primary driver of the neurodegenerative process. While these data somehow suggest that in mixed cases the quantitatively predominant pathology determines the characteristic clinical pictures, a large clinico-pathological correlative study using conventional semi-quantitative methodology found in a subset of clinically diagnosed DLB cases only severe neocortical $\tau$ pathology and a complete lack of LB pathology [105]. Recently, Irwin and colleagues demonstrated that $\tau$ pathology in LBD with dementia independently predicted a shorter time interval between motor symptom and dementia onset as well as shorter overall survival [61], clearly indicating that-if present $-\tau$ plays a central role in the disease process of LBD and that the co-occurrence of both $\mathrm{AD}$ and DLB pathology is likely to have an aggravating effect on disease progression. Respective data from neuropathological post-mortem studies are corroborated by in vivo imaging studies showing higher amyloid and $\tau$ levels in LBD compared to controls [46, 47]. While AD pathology is the most important co-morbidity in LBD cases, they may also show other pathologies such as cerebrovascular disease to varying degrees of severity in up to $75 \%$ [67] and TDP-43 pathology in over $30 \%$ of cases [95]. More quantitative data on the amount of pathological 
burden in large clinico-pathological cohorts are needed to clarify the relative influence of $\mathrm{A} \beta, \tau, \alpha$-syn, and TDP-43 on the clinical picture. This would pave the way for novel and more subtle clinico-pathological phenotypes, which, together with biomarkers, would allow to diagnose patients based on the actual underlying pathology.

Genetic data provide a tenuous link between synucleinopathies and tauopathies. $\mathrm{H} 1 \tau$ haplotype is associated with increased risk of PD [155], and has recently been associated with increased $\alpha$-syn aggregation in DLB in a small post-mortem study [25]. There is also cross-talk between $\alpha$-syn and $\tau$ in terms of disease-associated mutations. Mutations in or replications of the SCNA gene encoding $\alpha$-syn that cause familial PD can also cause cognitive symptoms including dementia [104, 113, 126]. A recent genetic study indicates that the p.A152T variant of MAPT is likely associated with a higher risk of DLB [84]. Another potential genetic link between $\tau$ and $\alpha$-syn is LRRK2. LRRK2 mutations usually give rise to $\alpha$-syn pathology [52], but sometimes, they also cause tangle pathology. $\tau$ and $\alpha$-syn pathology can also occur hand in hand without amyloid plaque pathology in rare cases, e.g., with hereditary spastic paraplegia due to SPG 7 mutations [148].

In addition to genetic data implying causative links between tauopathies and synucleinopathies, there are also multiple indications that pathological forms of $\tau$ and $\alpha$-syn physically co-aggregate within neuronal cytoplasm [104]. Using double immunofluorescence labeling and mass-spectrometry, $\tau$ and $\alpha$-syn have been observed in several studies to aggregate together in the same tangles, LB, and Lewy Neurites in PD and DLB brain [5, 24, 62]. Importantly, one recent study using novel conformationspecific antibodies demonstrated that toxic oligomeric forms of $\tau$ and $\alpha$-syn accumulate together in PD and DLB [122]. In vitro, $\alpha$-syn binds directly to $\tau$ via the microtubule-binding region of the $\tau$ protein and the $\mathrm{C}$-terminus of $\alpha$-syn [68]. This interaction is affected in a complex and as yet not completely understood manner by both phosphorylation and disease-associated mutations in the proteins $[36,104]$. It is possible that $\tau$ and $\alpha$-syn through their binding can cross-seed aggregation. Amyloidogenic proteins share some common characteristics in terms of their aggregation with a typically slow initial aggregation that becomes much faster after the process begins due to the new aggregates templating or seeding further aggregation [81]. This seeding process is not only relevant to the formation of large fibrils but also to the formation of oligomeric forms of proteins, which are likely the toxic species in the brain [81]. The seeding process is not necessarily limited to seeds made from the aggregating protein. Indeed, cross-seeding, in which "seeds"-some type of small aggregate-from one protein can induce aggregation of another protein-has been demonstrated across many different proteins. There is a small amount of evidence suggesting that $\tau$ and $A \beta$ may cross-seed the formation of toxic aggregates in vitro [49]. Much more evidence implicates cross-seeding between $\alpha$-syn and $\tau$. In vitro, co-incubation of $\alpha$-syn and $\tau$ synergistically promotes aggregation of both proteins [41], and in cultured neurons expressing FTDP-17 mutant $\tau$, synthetic aggregates of $\alpha$-syn seeded $\tau$ [50]. However, the cross-seeding of these proteins is not always reproduced, for example, using a sensitive FRET-based detection method, $\tau$ and $\alpha$-syn did not cross-seed [55]. These conflicting results may be due to the ability of specific "strains" or confirmations of aggregates of the proteins, which induce the seeding, which has been observed for $\tau[22,37], \alpha$-syn [111], and cross-seeding between them [50]. Similarly, distinct strains of $A \beta$ have been observed, which induce different types of aggregates in vivo [133, 159]. Crossseeding between $A \beta$ and $\alpha$-syn has been observed in vitro [109], along with hybrid oligomer formation [149]. Further work is warranted on understanding the cross-seeding process, and particularly on whether this causes the formation of toxic oligomeric species of the proteins.

Transgenic mouse models of tauopathies and synucleinopathies also support the idea of synergistic interactions of $\tau$ and $\alpha$-syn in exacerbating neurodegenerative phenotypes. Overexpressing $\alpha$-syn in transgenic mice causes $\tau$ phosphorylation $[51,160]$. Combining pathologies in mice overexpressing fAD mutations in $A P P$ and PSEN1, FTDP-17 mutant MAPT, and PD associated $S C N A$, there is a synergistic effect of the pathological proteins resulting in exacerbated pathological and behavioral phenotypes [23]. Knocking out $\tau$, however, does not prevent $\alpha$-syn-related motor deficits in two models of $\mathrm{PD}$, indicating that these proteins in addition to having synergistic effects can act independently to confer toxicity [103]. In wild-type mice injected with $\alpha$-syn fibrils, both $\tau$ and TDP-43 aggregate in addition to $\alpha$-syn [94]. There is also a substantial amount of evidence for crosstalk between $\mathrm{A} \beta$ and $\alpha$-syn pathologies. NMR evidence shows molecular interactions between these proteins [91], and in a double transgenic mouse model, $A \beta$ exacerbates $\alpha$-syn accumulation and neuronal deficits [92]. A $\beta$ induces phosphorylation of $\alpha$-syn at Ser129 in vitro and pSer129 $\alpha$-syn in brain tissue homogenates is related to the level of $A \beta$ and Braak NFT stage [135]. Similar to Alzheimer's disease, there is also evidence that synaptic degeneration is important in synucleinopathies with pathology associated with synaptic toxicity in vitro and in vivo [127, 154]. Less is known about molecular interactions of pathological proteins in synapse degeneration in synucleinopathies. $\tau$ reduction did not prevent motor deficits in $\alpha$-syn overexpressing mice, indicating that $\tau$ is not necessary for synaptic deficits in this line [103]. 


\section{The frontotemporal lobar degeneration: amyotrophic lateral sclerosis (FTLD-ALS) spectrum and beyond}

Both FTLD and ALS are heterogeneous diseases that can be sub-divided by their pathological lesions. Over the past few years, a substantial overlap has been observed in the pathologies, genetics, and clinical phenotypes of these complex diseases. FTLD can be subclassified in disorders that accumulate (1) $\tau$, i.e., FTLD-tau, (2) TDP43 , i.e., FTLD-TDP, and (3) other FTLD-forms that accumulate other proteins (e.g., fused in sarcoma (FUS) etc.) [90]. FTLD-TDP and ALS share neuronal TDP-43 aggregates and a certain number of ALS cases also develop FTLD-TDP and vice versa [107].

FTLD-tau comprises several morphologically different tauopathies: Pick's disease (PiD), corticobasal degeneration (CBD), progressive supranuclear palsy (PSP), argyrophilic grain disease (AGD), and neurofibrillary tanglepredominant dementia (NFTD) [90]. All these diseases have in common that $\tau$ is the sole protein that aggregates in these disorders. These diseases usually affect individuals below 70 years of age and concomitant $\mathrm{AD}$-associated $\mathrm{A} \beta$ and $\tau$ as well as TDP-43 and LBD-associated $\alpha$-syn may potentially be present but are only rarely seen [147] and hence not assumed to influence the disease process. Moreover, $\tau$ pathology in FTLD-tau is, except for NFTD, not restricted to neurons and neuronal processes. It also develops in astrocytes (astrocytic plaques in CBD, tufted astrocytes in PSP, $\tau$-positive astrocytes in AGD) and oligodendrocytes (coiled bodies in AGD, CBD, PSP, PiD) [33]. Except for AGD, FTLD-tau disorders cause dementia and in most cases do not show co-pathologies [147]. AGD is usually present with low-level AD-related pathology and such cases do not show clinical dementia [72, 145]. Demented AGD cases, however, showed significantly more severe $\mathrm{AD}$-related pathology $(\mathrm{A} \beta$-plaques and NFTs) than non-demented AGD cases but less than in demented cases that had pure AD pathology, suggesting additive effects of AGD and AD pathology [72, 145]. $\tau$ pathology is also observed in some ALS cases, where it has been reported to correlate with cognitive decline [162].

FTLD-TDP is characterized by intracellular aggregates of phosphorylated TDP-43 in the neuronal cytoplasm, dendrites [107] as well as in oligodendroglial cells [106]. In FTLD-TDP and ALS cases, not only full length TDP43 aggregates are found, but also truncated fragments, mainly C-terminal fragments of TDP-43, are also found [107]. In a subset of FTLD-TDP and ALS cases, hexanucleotide repeat expansions in the chromosome 9 open reading frame 72 (C9ORF72) have been seen. In these mutation carriers, dipeptide aggregates corresponding to abnormal translation of the pathological hexanucleotide repeats can be seen in the cytoplasm of neurons [101]. However, these aggregates do not correlate with disease severity or the coexisting TDP-43 pathology in the studies reported so far. The amount of TDP-43 pathology correlates more closely with the clinical severity of the disease in the studies conducted to date [89]. TDP-43 pathology in patients with the behavioral variant of FTLD-TDP (FTLD-TDP cases that show characteristic behavioral changes as key feature of the disease = bvFTLD-TDP) and with sporadic ALS show a characteristic pattern that suggests anatomical stages of TDP-43 pathology spreading that differed among bvFTLD-TDP and ALS $[16,18]$.

TDP-43 pathology is also found in AD cases [4, 153]. Recently, Josephs and colleagues reported that TDP43 pathology in $\mathrm{AD}$ is seen in over $50 \%$ of cases where it spreads in a distinct pattern [70,71], which was also observed in LBD and aged controls by others [95]. Moreover, colocalization of phosphorylated TDP-43 and $\tau$-containing NFTs has been reported but it is not yet clear whether this finding is due to unspecific co-staining of NFTs with the pTDP-43 antibody or whether indeed phosphorylated TDP-43 accumulates in NFTs. A similar questionable colocalization of $\tau$ and TDP-43 is speculated in granulovacuolar degeneration (GVD) [75]. GVD has been shown to represent an AD-related lesion [139] exhibiting phosphorylated TDP-43 as well as numerous other proteins in neuronal cytoplasmic vacuoles including $\tau$ [34] and phosphorylated $\mathrm{A} \beta$ [83].

There is substantial overlap in the genetics of FTD and ALS [115]. Mutations in C9ORF72, TARDBP, FUS, VCP, $U B Q L N 2, S Q S T M 1$, and $C H M P 2 B$ have all been associated with both ALS and FTD [46, 84], and mutations in $h g R N P A 2 B 1$ and can cause multisystem proteinopathy and ALS [80]. TARDBP mutations (TDP-43 gene) can lead to FTLD-TDP and/or rare ALS cases. Usually, no other proteins are aggregated in non-age-related amounts in these cases [74]. However, a case report shows a TARDBP mutation in a $\mathrm{AAD}$ case indicating a potential link from TDP43 directly to $\mathrm{AD}$ [100]. C9ORF72 mutations go in most instances along with TDP-43 pathology either with a FTLD-TDP or an ALS-related pattern $[31,116]$. In single cases, AD-related pathology also occurred as relevant pathological lesion in C9ORF72 mutation carriers, but the interpretation of this finding is controversial [19, 30, 54]. One of the most interesting aspects of C9ORF72 mutations is that in families with a distinct C9ORF72 mutation, the same mutation in some family members causes FTLD, whereas other family members with the same mutation developed ALS [20]. As such, other factors than the mutations appear to act as disease modifiers with impact on the primary vulnerability of distinct neurons. Since the 
C9orf72-related dipeptide aggregates do not correlate with the clinical symptomatology but with the TDP-43 pathology $[107,121]$, it is tempting to speculate that TDP-43-specific properties play a role in the primary targeting of the disease. In rare cases, mutations in the valosin-containing protein lead to FTLD-TDP or ALS [158]. Here, nuclear TDP-43-valosin-containing protein aggregates are the predominant lesion although cytoplasmic TDP-43 aggregates can also in different amounts [107, 121]. In this disorder, similar aggregates were found in skeletal muscle and in the myocardium $[58,158]$.

Pathological proteins typically associated with ALS and FTLD also show multiple mutual interactions including co-aggregation [10]. An interesting phenomenon emerging in the ALS protein aggregation literature is the role of low complexity domains in the RNA-binding proteins implicated in disease pathogenesis contributing to pathological protein aggregation. Low complexity domains mediate liquid-liquid phase separation which in healthy cells contributes to the assembly of membrane-less organelles such as RNA transport granules and stress granules; but in disease, the liquid phase transition initiates fibrillization of aggregates [99]. This may explain the co-aggregation of different low complexity domain-containing proteins such as TDP43 and FUS [79]. Interestingly, dipeptide repeat proteins produced from unconventional non-ATG dependent translation of C9ORF72 expansions, the most common cause of ALS and FTLD, have recently been found to interact with RNA-binding proteins with low complexity sequence domains in Drosophila [86]. This finding provides a potentially unifying mechanism for the disparate causes of ALS/FTLD converging on disrupted phase transitions that impair the assembly, dynamics, and function of membraneless organelles that cause widespread cellular abnormalities including impairments in nucleolar function, nucleocytoplasmic transport, RNA splicing, translation, and abnormal protein aggregation.

\section{Discussion}

Here, we have reviewed neuropathological and experimental findings, which together point to pathogenic links between the aggregation of A $\beta, \tau$, TDP-43, and $\alpha$-syn. These links are most evident in fAD cases with mutations in the APP, PSEN1, or PSEN2 genes because these cases often show aggregates of all four proteins in the brain due to mutation-driven production of high amounts of $A \beta$. Even a larger number of sporadic $\mathrm{AD}$ cases exhibit $\mathrm{A} \beta$, $\tau$, and TDP-43 aggregates [4, 70, 153]. Given the fact that $\tau$-aggregates develop in restricted areas of the brain before A $\beta$, TDP-43, and $\alpha$-syn lesions occur, one could speculate that $\tau$ pathology initiates $\mathrm{AD}$ and the aggregation of other proteins is just a secondary phenomenon. However, most people will accumulate brainstem $\tau$ pathology (usually between 40 and 50 years of age) [15] but only $32 \%$ will develop symptomatic $\mathrm{AD}$ in their lifetimes [3], and genetic evidence strongly implicates changes in $A \beta$ as crucial for initiating the disease process. Thus, $\tau$ pathology alone appears not to be sufficient to develop $A D$ as defined according to the recommended criteria [60], $A \beta$ pathology must also be involved. In other words, one can hypothesize that accumulation and aggregation of abnormal $\tau$-protein aggregates is an age-related phenomenon, which becomes overtly pathogenic and allowed to spread throughout the brain in the presence of $A \beta$ aggregates. Post-translationally modified forms of $A \beta$, such as $A \beta_{\mathrm{N} 3 \mathrm{pE}}$ and ${ }_{\mathrm{pSer} 8} \mathrm{~A} \beta$, may play an important role in the maturation of these aggregates [117]. Thus, maturation of protein aggregates, especially $\mathrm{A} \beta$ aggregates, appears to play a major role in the development of the disease [117]. In animal models for $A \beta$ pathology, $A \beta$ pathology alone is not sufficient to develop the full spectrum of AD pathology [39, 56, 134], although it is possible that this is in part due to the lifespan of rodents and in part due to differences in rodent and human $\tau$. Notwithstanding these caveats, the $\mathrm{A} \beta$-expressing animal model findings do support our hypothesis that $\tau$ pathology is an essential prerequisite for the development of AD but only in combination with $A \beta$. $\tau$-mutations in the absence of $A \beta$ (in man and in transgenic mice) lead mainly to a non-AD tauopathy and only very rarely are associated with AD [27, 59]. Moreover, the AD pathology in APP mutation carriers develops in adulthood after a normal childhood, i.e., when $\tau$ pathology becomes more and more prevalent in the published autopsy cohorts meaning that once abnormal $\tau$ occurs, the disease starts to develop, implying that $\tau$ is a prerequisite for disease.

Interactions between $\mathrm{A} \beta$ and TDP-43 or $\alpha$-syn may follow similar principles as that with $\tau$. The AD-specific progression pattern of AD-related TDP-43 aggregates [70] is different from that in FTLD-TDP and ALS cases [16, 18], which argues in favor of the idea that $\mathrm{A} \beta$ also exaggerates AD-related TDP-43 pathology. An argument for the interaction between $A \beta$ and $\alpha$-syn aggregates may be the frequent coincidence of full-blown AD and LBD pathology in demented patients that were clinically diagnosed as LBD patients (PDD and/or DLB), as well as the detection of LBDs in fAD cases $[88,125]$. Moreover, in the absence of $\mathrm{A} \beta$, TARDBP and SCNA mutations do not cause AD but ALS or PD [74, 100, 113].

Other proteins (in addition to $A \beta$ ) may also have triggering effects for neurodegeneration. The most attractive candidates are dipeptide aggregates in C9ORF72 hexanucleotide repeat mutation carriers developing ALS or FTLD-TDP with TDP-43 aggregates [101]. Moreover, a case report also suggests that mutant paraplegin $(S P G 7$ 
mutation) triggers both brainstem $\tau$ and $\alpha$-syn pathology in the absence of A $\beta$ [148]. That one MAPT mutation causes $\alpha$-syn changes in addition to $\tau$ pathology and that a mutation in LRRK2 can induce both, $\alpha$-syn-and in a few cases $\tau$-pathology [52, 84] further argues for a link between $\alpha$-syn and $\tau$.

Thus, several proteins can lead to neurodegeneration alone or in concert with one another. Intraneuronal and intracellular protein aggregates appear to be most relevant for the neurodegenerative process because they occur in all of the discussed neurodegenerative disorders and correlate well with cognitive decline and neuron loss [6, 45, 138]. It appears that the neuropathological type of neurodegenerative disorder simply reflects the circumstances of protein aggregation and that the pathogenic process of protein aggregation behind the phenotype has common principles in several neurodegenerative disorders, such as spreading of disease-related pathology [12, 14, 17, 143] and the involvement of post-translationally modified proteins in the disease-specific aggregates [38, 107, 140].

An argument for the hypothesis that the "phenotype of neurodegeneration" is the result of a critical accumulation of soluble and/or insoluble protein aggregates in neuronsregardless of the protein that aggregates - is provided by an artificial mouse model that produces intraneuronal $A \beta$ aggregates after cleavage from an enkephalin-signal-peptide $\mathrm{A} \beta_{42}$ construct, which shows significant neuron loss and an ALS-like phenotype with serious motor dysfunction (APP48 mice) [1]. Under this artificial paradigm, $\mathrm{A} \beta$ and/or its soluble and/or insoluble aggregates show different neurodegenerative effects than under the more ADrelated paradigm of APP overexpression [118]. However, post-translational modification of $A \beta$ similar to that seen in $\mathrm{AD}$ cases also occurred in the intracellular $\mathrm{A} \beta_{42}$ aggregates in this artificial mouse model [118] indicating that post-translational modifications may play an important role for the neurodegeneration process in general. Thus, artificial expression of an aggregation-prone protein in neurons causes neurodegeneration similar to other intraneuronal proteins that develop aggregates such as $\tau$ or TDP-43, whereas mainly extracellular deposition of the same protein had only limited effects supporting the idea that the intracellular protein accumulation may be a prerequisite for neurodegeneration, whereas extracellular $A \beta$ aggregates may catalyze spreading of intracellular aggregates while interacting and aggregating with the respective proteins.

The above-mentioned considerations argue against the classical view of the amyloid cascade hypothesis insofar as $\mathrm{A} \beta$ does not seem to the one and only player that causes all the rest of $\mathrm{AD}$ pathology. Amyloid as a key factor in $\mathrm{AD}$ pathogenesis is strongly supported, particularly by genetics of fAD, but it is also clear that alone, amyloid pathology is insufficient to drive neurodegeneration. The weight of the evidence on mechanisms of neuron loss in $\mathrm{AD}$ sides with $\tau$ being the driving toxic force. The data we have summarized here on co-occurrence of amyloid and $\tau$-pathologies in human brain and their mechanistic interactions in model systems support the intriguing possibility that in sporadic AD, age-related $\tau$-accumulation as observed in PART occurs earlier and independently from $A \beta$, thus representing a prerequisite for $A \beta$ to kick off the pathogenesis of AD. In the event that both proteins in an aggregated form co-occur in the brain, they appear to become particularly toxic and presumably interact to lead to the devastating neurodegeneration in AD. Lesions typical for other neurodegenerative disorders or vascular lesions may co-exist and either interact with the AD-related protein aggregates or producing brain lesions that are added to the AD-related neurodegeneration. Other tauopathies, TDP-43 proteinopathies, and synucleinopathies may follow a similar cascade of prerequisite lesion plus secondary disease-specific pathogenic event as depicted in Fig. 3.

One critical point in this cascade hypothesis is the point that mutation-driven disease might need a prerequisite lesion. One can argue that the mutations will drive even the initial lesions. However, if this would be the case, mutation-driven neurodegenerative disorders should manifest earlier in life during childhood because the mutant genes are expressed even at that age. However, most frequently, these disorders manifest usually in the 4th-6th decade of life or later [29, 42, 59, 129, 130, 137]. Accordingly, an age-related event seems to be required before the mutant protein can set a disease-specific pathogenic event. This concept is to some degree in line with the two-hit concept for TDP-43-proteinopathies [112].

The accumulation of misfolded proteins in the human brain is clearly associated with advanced age. However, the underlying mechanisms of this age-associated phenomenon are still unclear and the respective role of, e.g., DNA damage, autophagy impairment, cellular senescence, oxidative stress, and mitochondrial dysfunction are yet to be elucidated. Such elucidation may also provide further insights into cerebral multimorbidity as the age-associated impairment of underlying mechanisms to maintain cellular homeostasis may vary between individuals, possibly based on their respective genetic background. For example, GWAS studies point toward a role of disturbed autophagic/lysosomal function in DLB but not in PDD, while the opposite was suggested for mitochondrial dysfunction. Therefore, the pathomechanisms of cerebral multimorbidity may not only be explained by protein-protein interactions but also by age-associated failure of basic cellular mechanisms, which may show individual variations.

The presence of multiple protein aggregates in patients with neurodegenerative symptoms indicates that in many cases not only one disease, such as AD is responsible for 


\section{Cascade hypothesis for neurodegenerative disorders}

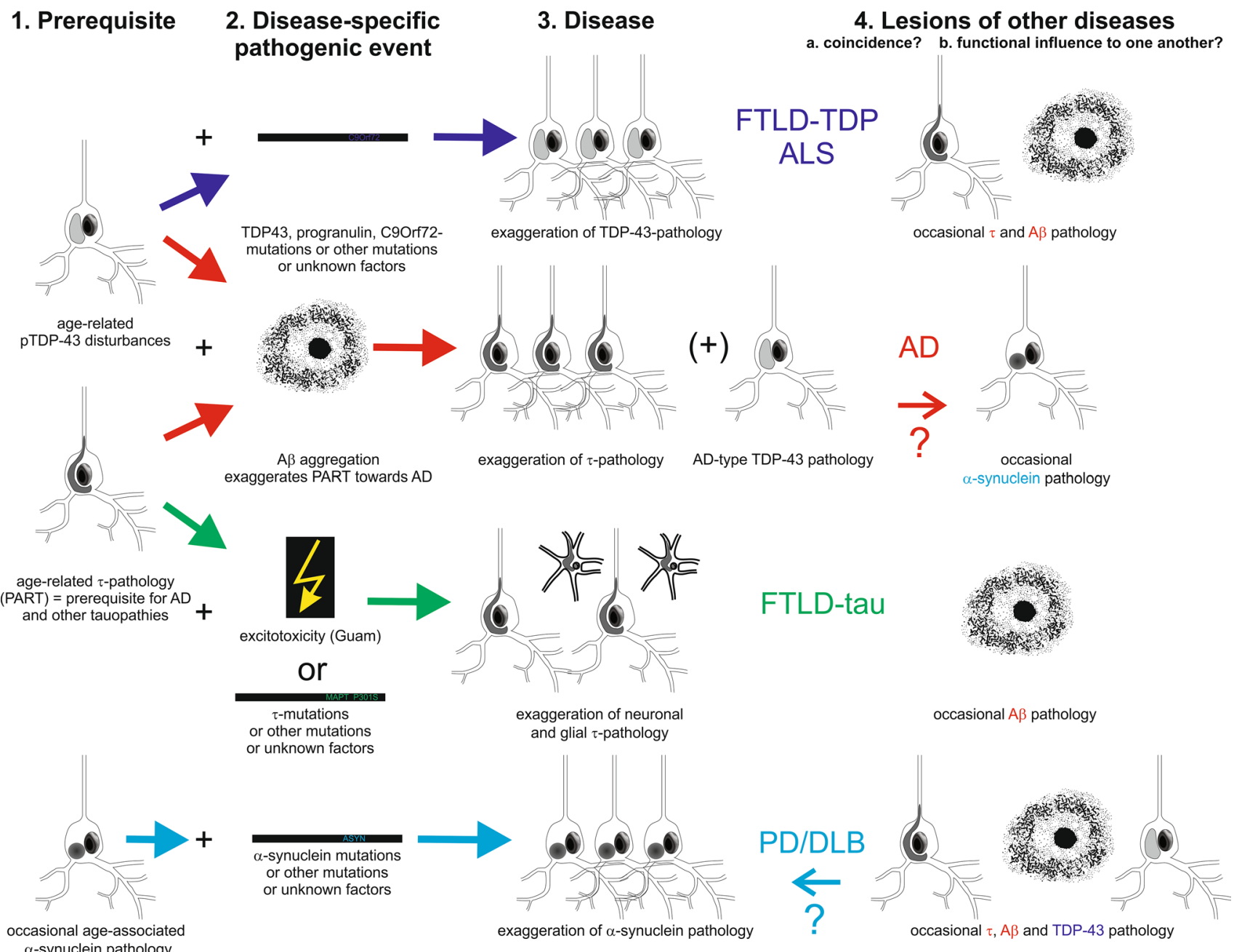

Fig. 3 Cascade hypothesis for neurodegenerative disorders: Pathological protein interactions contribute to neurodegeneration. Schematic representation of the interplay between the different neurodegenerative protein aggregates and their related diseases. As a result of the current knowledge about disease progression and experimental evidence about protein-aggregate interactions in vivo an in vitro, we hypothesize that abnormal $\tau$-protein accumulation is an event that happens during aging in the brain stem of nearly everyone above 40 years of age [15] ( 1 prerequisite for disease). AD appears to develop when $A \beta$ aggregates occur and initiate more pathological accumulation of $\tau$ and its spread through the brain (2 disease-specific pathogenic event and 3 disease). Maturation of plaque-associated and soluble/dispersible $\mathrm{A} \beta$-aggregates thereby appear to be a critical event in the progression of the disease. Abnormal $\tau$-protein aggregates, TDP-43 aggregates, and $\alpha$-syn aggregates occur in smaller subset of

the clinical symptoms but that secondary components such as TDP-43 inclusions or even vascular lesions contribute to the development of the symptoms of a given patient as well. Thus, diagnostic and therapeutic regimes must not only focus on the most evident pathology such individuals during age as shown in Fig. 1 (it is not clear whether it is a result of aging or the early stages of neurodegeneration). Once $\mathrm{A} \beta$ aggregates prevail in a certain amount or biochemical maturation stage, it is tempting to speculate that these $A \beta$ aggregates may also exaggerate/catalyze TDP-43 or possibly also $\alpha$-syn pathology in pattern similar to that seen in AD or AD-LBD ( $4 \alpha$-syn pathology is typical for $\mathrm{PD} / \mathrm{DLB}$ and can be interpreted as pure coincidence or as influenced by/influencing $\mathrm{AD}$ pathology or its clinical picture). In the absence of $\mathrm{A} \beta$ and/or after exposure to other triggers (e.g., diseasespecific mutations, excitotoxicity in Guam disease [35]) $\tau, \alpha$-syn, and TDP-43 aggregates develop other neurodegenerative disorders such as FTLD-tau, FTLD-TDP, ALS, or PD/DLB. $A D$ Alzheimer's disease, FTLD frontotemporal lobar degeneration, $A L S$ amyotrophic lateral sclerosis (synonymous with MND-motor neuron disease), $L B D$ Lewy body disease [including Parkinson's disease (PD) and DLB]

as $\mathrm{AD}$ but also need to take into account other neurodegenerative and vascular lesions. Thus, for the clinical diagnostic procedure, it appears to be essential to screen not only for AD lesions, but also for $\alpha$-syn, TDP-43, and for vascular lesions. 


\section{Conclusion}

$\tau$, TDP-43, and $\alpha$-syn alone lead to specific neurodegenerative disorders that do not necessarily show multiple proteins aggregating in the respective disorders such as in FTLD-tau, FTLD-TDP, ALS, and PD, whereas AD appears to have at least a two-step pathogenesis with alterations in $\mathrm{A} \beta$ likely initiating the actual disease process, but with $\tau$ accumulation and spread through the brain being the essential step to cause disease symptoms. It is possible that pathological accumulations of $\tau$ independent of $\mathrm{A} \beta$ are a prerequisite for $\mathrm{AD}$ with extracellular $\mathrm{A} \beta$ being the second step that exaggerates or catalyzes the pathological process leading to clinical dementia. Similarly, TDP-43 and $\alpha$-syn pathologies probably develop independently (and can cause clinical disease) but extracellular $\mathrm{A} \beta$ may aggravate or catalyze the spread of these pathologies throughout the brain. Accumulating evidence suggests that the fibrillar aggregates of all of these proteins are not likely directly toxic to neurons but reflect-and in some cases exacerbate- the accumulation of toxic soluble forms of the proteins.

Data from human autopsy material and experimental model systems indicate multiple interactions of pathological proteins both directly in terms of co-aggregation and indirectly, for example, involvement in the same molecular pathways to neurodegeneration. Recent data also make it tempting to speculate that pathological proteins interact in the process of spread of the disease through the brain. However, our knowledge on cerebral multimorbidity is still limited as this multimorbidity shows considerable qualitative and quantitative heterogeneity between cases, and hence large-scale studies on human post-mortem brains, which combine both detailed clinical data and quantitative data on the amount of proteinaggregate burden, are needed to further our understanding of protein-protein interactions in the multimorbid old brain. Understanding these interactions will be important to develop effective therapeutic targets to reduce toxicity and possibly to stop these diseases in their tracks (Fig. 3).

Acknowledgements TS-J is funded by Alzheimer's Research UK and the Scottish Chief Scientist's Office, Alzheimer's Society, a Wellcome Trust ISSF grant, and the European Research Council (ALZSYN). DRT received research grants from Alzheimer Forschung Initiative, Germany \#13803, from FWO-Odysseus funding, and from the government of Vlanderen VIND (Vlaamse Impulsfinanciering voor Netwerken voor Dementieonderzoek). JA used tissue for this study which was provided by the Newcastle Brain Tissue Resource, which is funded in part by a grant from the UK Medical Research Council (Grant Number G0400074) and by Brains for Dementia research, a joint venture between Alzheimer's Society and Alzheimer's Research UK. We gratefully acknowledge Dominic Walsh and Virginia Lee for providing antibodies used in Fig. 2.
Compliance with ethical standards

Conflict of interest DRT received consultancies from Covance Laboratories (UK) and GE-Healthcare (UK), received a speaker honorarium from GE-Healthcare (UK), and collaborated with Novartis Pharma Basel (Switzerland). TS-J collaborates with Cognition Therapeutics (USA).

Open Access This article is distributed under the terms of the Creative Commons Attribution 4.0 International License (http://creativecommons.org/licenses/by/4.0/), which permits unrestricted use, distribution, and reproduction in any medium, provided you give appropriate credit to the original author(s) and the source, provide a link to the Creative Commons license, and indicate if changes were made.

\section{References}

1. Abramowski D, Rabe S, Rijal Upadhaya A, Reichwald J, Danner S, Staab D, Capetillo-Zarate E, Yamaguchi H, Saido TC, Wiederhold KH et al (2012) Transgenic expression of intraneuronal Abeta42 but not Abeta40 leads to cellular Abeta lesions, degeneration and functional impairment without typical Alzheimer's disease pathology. J Neurosci 32:1273-1283

2. Alafuzoff I, Arzberger T, Al-Sarraj S, Bodi I, Bogdanovic N, Braak H, Bugiani O, Del Tredici K, Ferrer I, Gelpi E et al (2008) Staging of neurofibrillary pathology in Alzheimer's disease. A study of the BrainNet Europe Consortium. Brain Pathol 18:484-496

3. Alzheimer's Association (2016) 2016 Alzheimer's disease facts and figures. Alzheimers Dement 12:459-509

4. Amador-Ortiz C, Lin WL, Ahmed Z, Personett D, Davies P, Duara R, Graff-Radford NR, Hutton ML, Dickson DW (2007) TDP-43 immunoreactivity in hippocampal sclerosis and Alzheimer's disease. Ann Neurol 61:435-445. doi:10.1002/ana.21154

5. Arima K, Mizutani T, Alim MA, Tonozuka-Uehara H, Izumiyama Y, Hirai S, Ueda K (2000) NACP/alpha-synuclein and tau constitute two distinctive subsets of filaments in the same neuronal inclusions in brains from a family of parkinsonism and dementia with Lewy bodies: double-immunolabeling fluorescence and electron microscopic studies. Acta Neuropathol 100:115-121

6. Arriagada PV, Growdon JH, Hedley-Whyte ET, Hyman BT (1992) Neurofibrillary tangles but not senile plaques parallel duration and severity of Alzheimer's disease. Neurology 42:631-639

7. Attems J, Jellinger K, Thal DR, Van Nostrand W (2011) Review: sporadic cerebral amyloid angiopathy. Neuropathol Appl Neurobiol 37:75-93. doi:10.1111/j.1365-2990.2010.01137.x

8. Attems J, Thomas A, Jellinger K (2012) Correlations between cortical and subcortical tau pathology. Neuropathol Appl Neurobiol 38:582-590. doi:10.1111/j.1365-2990.2011.01244.x

9. Bancher C, Brunner C, Lassmann H, Budka H, Jellinger $\mathrm{K}$, Wiche G, Seitelberger F, Grundke-Iqbal I, Iqbal K, Wisniewski HM (1989) Accumulation of abnormally phosphorylated tau precedes the formation of neurofibrillary tangles in Alzheimer's disease. Brain Res 477:90-99

10. Blokhuis AM, Groen EJN, Koppers M (2013) Protein aggregation in amyotrophic lateral sclerosis. Acta Neuropathol 125:777-794. doi:10.1007/s00401-013-1125-6 
11. Braak E, Braak H, Mandelkow EM (1994) A sequence of cytoskeleton changes related to the formation of neurofibrillary tangles and neuropil threads. Acta Neuropathol 87:554-567

12. Braak H, Braak E (1991) Neuropathological stageing of Alzheimer-related changes. Acta Neuropathol 82:239-259

13. Braak H, Del Tredici K (2011) The pathological process underlying Alzheimer's disease in individuals under thirty. Acta Neuropathol 121:171-181

14. Braak H, Del Tredici K, Rub U, de Vos RA, Jansen Steur EN, Braak E (2003) Staging of brain pathology related to sporadic Parkinson's disease. Neurobiol Aging 24:197-211

15. Braak H, Thal DR, Ghebremedhin E, Del Tredici K (2011) Stages of the pathological process in Alzheimer's disease: age categories 1 year to 100 years. J Neuropathol Exp Neurol 70:960-969

16. Brettschneider J, Del Tredici K, Irwin DJ, Grossman M, Robinson JL, Toledo JB, Fang L, Van Deerlin VM, Ludolph AC, Lee VM et al (2014) Sequential distribution of pTDP-43 pathology in behavioral variant frontotemporal dementia (bvFTD). Acta Neuropathol 127:423-439. doi:10.1007/s00401-013-1238-y

17. Brettschneider J, Del Tredici K, Lee VM, Trojanowski JQ (2015) Spreading of pathology in neurodegenerative diseases: a focus on human studies. Nat Rev Neurosci 16:109-120. doi:10.1038/nrn3887

18. Brettschneider J, Del Tredici K, Toledo JB, Robinson JL, Irwin DJ, Grossman M, Suh E, Van Deerlin VM, Wood EM, Baek Y et al (2013) Stages of pTDP-43 pathology in amyotrophic lateral sclerosis. Ann Neurol 74:20-38. doi:10.1002/ana.23937

19. Cacace R, Van Cauwenberghe C, Bettens K, Gijselinck I, van der Zee J, Engelborghs S, Vandenbulcke M, Van Dongen J, Baumer V, Dillen L et al (2013) C9orf72 G4C2 repeat expansions in Alzheimer's disease and mild cognitive impairment. Neurobiol Aging 34(1712):e1711-e1717. doi:10.1016/j. neurobiolaging.2012.12.019

20. Cerami C, Marcone A, Galimberti D, Zamboni M, Fenoglio C, Serpente M, Scarpini E, Cappa SF (2013) Novel evidence of phenotypical variability in the hexanucleotide repeat expansion in chromosome 9. J Alzheimers Dis 35:455-462. doi:10.3233/ JAD-122302

21. Choi SH, Kim YH, Hebisch M, Sliwinski C, Lee S, D'Avanzo C, Chen H, Hooli B, Asselin C, Muffat J et al (2014) A threedimensional human neural cell culture model of Alzheimer's disease. Nature 515:274-278. doi:10.1038/nature13800

22. Clavaguera F, Akatsu H, Fraser G, Crowther RA, Frank S, Hench J, Probst A, Winkler DT, Reichwald J, Staufenbiel $M$ et al (2013) Brain homogenates from human tauopathies induce tau inclusions in mouse brain. Proc Natl Acad Sci USA 110:9535-9540. doi:10.1073/pnas.1301175110

23. Clinton LK, Blurton-Jones M, Myczek K, Trojanowski JQ, LaFerla FM (2010) Synergistic Interactions between Abeta, tau, and alpha-synuclein: acceleration of neuropathology and cognitive decline. J Neurosci 30:7281-7289. doi:10.1523/ JNEUROSCI.0490-10.2010

24. Colom-Cadena M, Gelpi E, Charif S, Belbin O, Blesa R, Marti MJ, Clarimon J, Lleo A (2013) Confluence of alpha-synuclein, tau, and beta-amyloid pathologies in dementia with Lewy bodies. J Neuropathol Exp Neurol 72:1203-1212. doi:10.1097/ NEN.0000000000000018

25. Colom-Cadena M, Gelpi E, Marti MJ, Charif S, Dols-Icardo O, Blesa R, Clarimon J, Lleo A (2013) MAPT H1 haplotype is associated with enhanced alpha-synuclein deposition in dementia with Lewy bodies. Neurobiol Aging 34:936-942. doi:10.1016/j.neurobiolaging.2012.06.015

26. Compta Y, Parkkinen L, O’Sullivan SS, Vandrovcova J, Holton JL, Collins C, Lashley T, Kallis C, Williams DR, de Silva R et al (2011) Lewy- and Alzheimer-type pathologies in Parkinson's disease dementia: which is more important? Brain 134:1493-1505. doi:10.1093/brain/awr031

27. Coppola G, Chinnathambi S, Lee JJY (2012) Evidence for a role of the rare p. A152T variant in MAPT in increasing the risk for FTD-spectrum and Alzheimer's diseases. Hum Mol Genet 21:3500-3512. doi:10.1093/hmg/dds161

28. Crary JF, Trojanowski JQ, Schneider JA, Abisambra JF, Abner EL, Alafuzoff I, Arnold SE, Attems J, Beach TG, Bigio EH et al (2014) Primary age-related tauopathy (PART): a common pathology associated with human aging. Acta Neuropathol 128:755-766. doi:10.1007/s00401-014-1349-0

29. Crook R, Ellis R, Shanks M, Thal LJ, Perez-Tur J, Baker M, Hutton M, Haltia T, Hardy J, Galasko D (1997) Early-onset Alzheimer's disease with a presenilin-1 mutation at the site corresponding to the Volga German presenilin-2 mutation. Ann Neurol 42:124-128

30. Davidson YS, Raby S, Foulds PG, Robinson A, Thompson JC, Sikkink S, Yusuf I, Amin H, DuPlessis D, Troakes C et al (2011) TDP-43 pathological changes in early onset familial and sporadic Alzheimer's disease, late onset Alzheimer's disease and Down's syndrome: association with age, hippocampal sclerosis and clinical phenotype. Acta Neuropathol 122:703-713. doi:10.1007/s00401-011-0879-y

31. DeJesus-Hernandez M, Mackenzie IR, Boeve BF, Boxer AL, Baker M, Rutherford NJ, Nicholson AM, Finch NA, Flynn H, Adamson J et al (2011) Expanded GGGGCC hexanucleotide repeat in noncoding region of C9ORF72 causes chromosome 9p-linked FTD and ALS. Neuron 72:245-256. doi:10.1016/j. neuron.2011.09.011

32. Dickson DW (1997) The pathogenesis of senile plaques. J Neuropathol Exp Neurol 56:321-339

33. Dickson DW, Kouri N, Murray ME, Josephs KA (2011) Neuropathology of frontotemporal lobar degeneration-tau (FTLD-tau). J Mol Neurosci 45:384-389. doi:10.1007/ s12031-011-9589-0

34. Dickson DW, Ksiezak-Reding H, Davies P, Yen SH (1987) A monoclonal antibody that recognizes a phosphorylated epitope in Alzheimer neurofibrillary tangles, neurofilaments and tau proteins immunostains granulovacuolar degeneration. Acta Neuropathol 73:254-258

35. Escobar-Khondiker M, Hollerhage M, Muriel MP, Champy P, Bach A, Depienne C, Respondek G, Yamada ES, Lannuzel A, Yagi $T$ et al (2007) Annonacin, a natural mitochondrial complex I inhibitor, causes tau pathology in cultured neurons. J Neurosci 27:7827-7837

36. Esposito A, Dohm CP, Kermer P, Bahr M, Wouters FS (2007) alpha-Synuclein and its disease-related mutants interact differentially with the microtubule protein tau and associate with the actin cytoskeleton. Neurobiol Dis 26:521-531. doi:10.1016/j.nbd.2007.01.014

37. Falcon B, Cavallini A, Angers R, Glover S, Murray TK, Barnham L, Jackson S, O'Neill MJ, Isaacs AM, Hutton ML et al (2015) Conformation determines the seeding potencies of native and recombinant Tau aggregates. J Biol Chem 290:1049-1065. doi:10.1074/jbc.M114.589309

38. Fujiwara H, Hasegawa M, Dohmae N, Kawashima A, Masliah E, Goldberg MS, Shen J, Takio K, Iwatsubo T (2002) alphaSynuclein is phosphorylated in synucleinopathy lesions. Nat Cell Biol 4:160-164. doi:10.1038/ncb748

39. Games D, Adams D, Alessandrini R, Barbour R, Berthelette P, Blackwell C, Carr T, Clemens J, Donaldson T, Gillespie $F$ et al (1995) Alzheimer-type neuropathology in transgenic mice overexpressing V717F beta-amyloid precursor protein. Nature 373:523-527

40. Ghetti B, Oblak AL, Boeve BF, Johnson KA, Dickerson BC, Goedert M (2015) Invited review: frontotemporal dementia 
caused by microtubule-associated protein tau gene (MAPT) mutations: a chameleon for neuropathology and neuroimaging. Neuropathol Appl Neurobiol 41:24-46. doi:10.1111/ nan. 12213

41. Giasson BI, Forman MS, Higuchi M, Golbe LI, Graves CL, Kotzbauer PT, Trojanowski JQ, Lee VM (2003) Initiation and synergistic fibrillization of tau and alpha-synuclein. Science 300:636-640

42. Goate A, Chartier-Harlin MC, Mullan M, Brown J, Crawford F, Fidani L, Giuffra L, Haynes A, Irving N, James L et al (1991) Segregation of a missense mutation in the amyloid precursor protein gene with familial Alzheimer's disease. Nature 349:704-706

43. Goedert M (2015) NEURODEGENERATION. Alzheimer's and Parkinson's diseases: the prion concept in relation to assembled $\mathrm{A} \beta$, tau, and $\alpha$-synuclein. Science 349:1255555. doi:10.1126/ science. 1255555

44. Goedert M, Spillantini MG, Jakes R, Rutherford D, Crowther RA (1989) Multiple isoforms of human microtubule-associated protein tau: sequences and localization in neurofibrillary tangles of Alzheimer's disease. Neuron 3:519-526

45. Gomez-Isla T, Price JL, McKeel DW Jr, Morris JC, Growdon JH, Hyman BT (1996) Profound loss of layer II entorhinal cortex neurons occurs in very mild Alzheimer's disease. J Neurosci $16: 4491-4500$

46. Gomperts SN (2014) Imaging the role of amyloid in PD dementia and dementia with Lewy bodies. Curr Neurol Neurosci Rep 14:472. doi:10.1007/s11910-014-0472-6

47. Gomperts SN, Locascio JJ, Makaretz SJ, Schultz A, Caso C, Vasdev N, Sperling R, Growdon JH, Dickerson BC, Johnson K (2016) Tau positron emission tomographic imaging in the Lewy body diseases. JAMA Neurol 73:1334-1341. doi:10.1001/ jamaneurol.2016.3338

48. Grundke-Iqbal I, Iqbal K, Quinlan M, Tung YC, Zaidi MS, Wisniewski HM (1986) Microtubule-associated protein tau. A component of Alzheimer paired helical filaments. J Biol Chem 261:6084-6089

49. Guo J-P, Arai T, Miklossy J, McGeer PL (2006) A $\beta$ and tau form soluble complexes that may promote self aggregation of both into the insoluble forms observed in Alzheimer's disease. Proc Natl Acad Sci USA 103:1953-1958. doi:10.1073/ pnas.0509386103

50. Guo JL, Covell DJ, Daniels JP, Iba M, Stieber A, Zhang B, Riddle DM, Kwong LK, Xu Y, Trojanowski JQ et al (2013) Distinct $\alpha$-synuclein strains differentially promote tau inclusions in neurons. Cell 154:103-117. doi:10.1016/j.cell.2013.05.057

51. Haggerty $\mathrm{T}$, Credle J, Rodriguez $\mathrm{O}$, Wills J, Oaks AW, Masliah E, Sidhu A (2011) Hyperphosphorylated Tau in an alpha-synuclein-overexpressing transgenic model of Parkinson's disease. Eur J Neurosci 33:1598-1610. doi:10.1111/j.1460-9568.2011.07660.x

52. Hardy J (2010) Genetic analysis of pathways to Parkinson disease. Neuron 68:201-206

53. Hardy J, Selkoe DJ (2002) The amyloid hypothesis of Alzheimer's disease: progress and problems on the road to therapeutics. Science 297:353-356

54. Harms M, Benitez BA, Cairns N, Cooper B, Cooper P, Mayo K, Carrell D, Faber K, Williamson J, Bird T et al (2013) C9orf72 hexanucleotide repeat expansions in clinical Alzheimer disease. JAMA Neurol 70:736-741. doi:10.1001/2013.jamaneurol.537

55. Holmes BB, Furman JL, Mahan TE, Yamasaki TR, Mirbaha H, Eades WC, Belaygorod L, Cairns NJ, Holtzman DM, Diamond MI (2014) Proteopathic tau seeding predicts tauopathy in vivo. Proc Natl Acad Sci USA 111:85. doi:10.1073/pnas.1411649111

56. Hsiao K, Chapman P, Nilsen S, Eckman C, Harigaya Y, Younkin S, Yang F, Cole G (1996) Correlative memory deficits, Abeta elevation, and amyloid plaques in transgenic mice. Science 274:99-102

57. Hu NW, Nicoll AJ, Zhang D, Mably AJ, O'Malley T, Purro SA, Terry C, Collinge J, Walsh DM, Rowan MJ (2014) mGlu5 receptors and cellular prion protein mediate amyloid-betafacilitated synaptic long-term depression in vivo. Nat Commun 5:3374. doi:10.1038/ncomms4374

58. Hubbers CU, Clemen CS, Kesper K, Boddrich A, Hofmann A, Kamarainen O, Tolksdorf K, Stumpf M, Reichelt J, Roth U et al (2007) Pathological consequences of VCP mutations on human striated muscle. Brain 130:381-393

59. Hutton M, Lendon CL, Rizzu P, Baker M, Froelich S, Houlden $\mathrm{H}$, Pickering-Brown S, Chakraverty S, Isaacs A, Grover A et al (1998) Association of missense and $5^{\prime}$-splice-site mutations in tau with the inherited dementia FTDP-17. Nature 393:702-705

60. Hyman BT, Phelps CH, Beach TG, Bigio EH, Cairns NJ, Carrillo MC, Dickson DW, Duyckaerts C, Frosch MP, Masliah E et al (2012) National Institute on Aging-Alzheimer's Association guidelines for the neuropathologic assessment of Alzheimer's disease. Alzheimers Dement 8:1-13

61. Irwin DJ, Grossman M, Weintraub D, Hurtig HI, Duda JE, Xie SX, Lee EB, Van Deerlin VM, Lopez OL, Kofler JK et al (2017) Neuropathological and genetic correlates of survival and dementia onset in synucleinopathies: a retrospective analysis. Lancet Neurol 16:55-65. doi:10.1016/S1474-4422(16)30291-5

62. Ishizawa T, Mattila P, Davies P, Wang D, Dickson DW (2003) Colocalization of tau and alpha-synuclein epitopes in Lewy bodies. J Neuropathol Exp Neurol 62:389-397

63. Ittner LM, Ke YD, Delerue F, Bi M, Gladbach A, van Eersel J, Wölfing H, Chieng BC, Christie MJ, Napier IA, Eckert A, Staufenbiel M, Hardeman E, Götz J (2010) Dendritic function of tau mediates amyloid- $\beta$ toxicity in Alzheimer's disease mouse models. Cell 142:387-397

64. Jack CR Jr (2014) PART and SNAP. Acta Neuropathol 128:773-776. doi:10.1007/s00401-014-1362-3

65. Jackson RJ, Rudinskiy N, Herrmann AG, Croft S, Kim JSM, Petrova V, Ramos-Rodriguez JJ, Pitstick R, Wegmann S, Garcia-Alloza $M$ et al (2016) Human tau increases amyloid $\beta$ plaque size but not amyloid $\beta$-mediated synapse loss in a novel mouse model of Alzheimer's disease. Eur J Neurosci 44:3056-3066

66. Jellinger KA, Attems J (2006) Does striatal pathology distinguish Parkinson disease with dementia and dementia with Lewy bodies? Acta Neuropathol 112:253-260. doi:10.1007/ s00401-006-0088-2

67. Jellinger KA, Attems J (2008) Prevalence and impact of vascular and Alzheimer pathologies in Lewy body disease. Acta Neuropathol 115:427-436. doi:10.1007/s00401-008-0347-5

68. Jensen PH, Hager H, Nielsen MS, Hojrup P, Gliemann J, Jakes $\mathrm{R}$ (1999) alpha-synuclein binds to Tau and stimulates the protein kinase A-catalyzed tau phosphorylation of serine residues 262 and 356. J Biol Chem 274:25481-25489

69. Jonsson T, Atwal JK, Steinberg S, Snaedal J, Jonsson PV, Bjornsson S, Stefansson H, Sulem P, Gudbjartsson D, Maloney $\mathrm{J}$ et al (2012) A mutation in APP protects against Alzheimer's disease and age-related cognitive decline. Nature 488:96-99. doi:10.1038/nature11283

70. Josephs KA, Murray ME, Whitwell JL, Parisi JE, Petrucelli L, Jack CR, Petersen RC, Dickson DW (2014) Staging TDP-43 pathology in Alzheimer's disease. Acta Neuropathol 127:441450. doi:10.1007/s00401-013-1211-9

71. Josephs KA, Murray ME, Whitwell JL, Tosakulwong N, Weigand SD, Petrucelli L, Liesinger AM, Petersen RC, Parisi JE, Dickson DW (2016) Updated TDP-43 in Alzheimer's disease staging scheme. Acta Neuropathol 131:571-585. doi:10.1007/ s00401-016-1537-1 
72. Josephs KA, Whitwell JL, Parisi JE, Knopman DS, Boeve BF, Geda YE, Jack CR Jr, Petersen RC, Dickson DW (2008) Argyrophilic grains: a distinct disease or an additive pathology? Neurobiol Aging 29:566-573

73. Jucker M, Walker LC (2013) Self-propagation of pathogenic protein aggregates in neurodegenerative diseases. Nature 501:45-51. doi:10.1038/nature12481

74. Kabashi E, Valdmanis PN, Dion P, Spiegelman D, McConkey BJ, Vande Velde C, Bouchard JP, Lacomblez L, Pochigaeva K, Salachas F et al (2008) TARDBP mutations in individuals with sporadic and familial amyotrophic lateral sclerosis. Nat Genet 40:572-574. doi:10.1038/ng.132

75. Kadokura A, Yamazaki T, Kakuda S, Makioka K, Lemere CA, Fujita Y, Takatama M, Okamoto K (2009) Phosphorylationdependent TDP-43 antibody detects intraneuronal dot-like structures showing morphological characters of granulovacuolar degeneration. Neurosci Lett 463:87-92

76. Kalaitzakis ME, Walls AJ, Pearce RK, Gentleman SM (2011) Striatal Abeta peptide deposition mirrors dementia and differentiates DLB and PDD from other parkinsonian syndromes. Neurobiol Dis 41:377-384. doi:10.1016/j.nbd.2010.10.005

77. Kapasi A, De Carlie C, Schneider JA (2017) Impact of multiple pathologies of the threshold for clinically overt dementia. Acta Neuropathol (in press)

78. Kay KR, Smith C, Wright AK, Serrano-Pozo A, Pooler AM, Koffie R, Bastin ME, Bak TH, Abrahams S, Kopeikina KJ et al (2013) Studying synapses in human brain with array tomography and electron microscopy. Nat Protoc 8:1366-1380. doi:10.1038/nprot.2013.078

79. Keller BA, Volkening K, Droppelmann CA, Ang LC, Rademakers R, Strong MJ (2012) Co-aggregation of RNA binding proteins in ALS spinal motor neurons: evidence of a common pathogenic mechanism. Acta Neuropathol 124:733-747. doi:10.1007/s00401-012-1035-Z

80. Kim HJ, Kim NC, Wang YD, Scarborough EA, Moore J (2013) Mutations in prion-like domains in hnRNPA2B1 and hnRNPA1 cause multisystem proteinopathy and ALS. Nature 495:467473. doi:10.1038/nature 11922

81. Knowles TP, Vendruscolo M, Dobson CM (2014) The amyloid state and its association with protein misfolding diseases. Nat Rev Mol Cell Biol 15(384):396. doi:10.1038/nrm3810

82. Kokubo Y, Taniguchi A, Hasegawa M, Hayakawa Y, Morimoto S, Yoneda M, Hirokawa Y, Shiraishi T, Saito Y, Murayama $S$ et al (2012) alpha-Synuclein pathology in the amyotrophic lateral sclerosis/parkinsonism dementia complex in the Kii Peninsula, Japan. J Neuropathol Exp Neurol 71:625-630. doi:10.1097/NEN.0b013e31825b9680

83. Kumar S, Wirths O, Stuber K, Wunderlich P, Koch P, Theil S, Rezaei-Ghaleh N, Zweckstetter M, Bayer TA, Brustle O et al (2016) Phosphorylation of the amyloid beta-peptide at Ser26 stabilizes oligomeric assembly and increases neurotoxicity. Acta Neuropathol 131:525-537. doi:10.1007/s00401-016-1546-0

84. Labbe C, Ogaki K, Lorenzo-Betancor O, Soto-Ortolaza AI, Walton RL, Rayaprolu S, Fujioka S, Murray ME, Heckman MG, Puschmann A et al (2015) Role for the microtubule-associated protein tau variant p. A152T in risk of alpha-synucleinopathies. Neurology 85:1680-1686. doi:10.1212/WNL.0000000000001946

85. Lauren J, Gimbel DA, Nygaard HB, Gilbert JW, Strittmatter SM (2009) Cellular prion protein mediates impairment of synaptic plasticity by amyloid-beta oligomers. Nature 457:11281132. doi:10.1038/nature07761

86. Lee K-HH, Zhang P, Kim HJ, Mitrea DM, Sarkar M, Freibaum BD, Cika J, Coughlin M, Messing J, Molliex A et al (2016) C9orf72 dipeptide repeats impair the assembly, dynamics, and function of membrane-less organelles. Cell 167:774. doi:10.1016/j.cell.2016.10.002
87. Lewis J, Dickson DW, Lin WL, Chisholm L, Corral A, Jones G, Yen SH, Sahara N, Skipper L, Yager D et al (2001) Enhanced neurofibrillary degeneration in transgenic mice expressing mutant tau and APP. Science 293:1487-1491. doi:10.1126/science.1058189

88. Lippa CF, Fujiwara H, Mann DM, Giasson B, Baba M, Schmidt ML, Nee LE, O'Connell B, Pollen DA, St George-Hyslop P et al (1998) Lewy bodies contain altered alpha-synuclein in brains of many familial Alzheimer's disease patients with mutations in presenilin and amyloid precursor protein genes. Am J Pathol 153:1365-1370

89. Mackenzie IR, Arzberger T, Kremmer E, Troost D, Lorenzl S, Mori K, Weng SM, Haass C, Kretzschmar HA, Edbauer D et al (2013) Dipeptide repeat protein pathology in C9ORF72 mutation cases: clinico-pathological correlations. Acta Neuropathol 126:859-879. doi:10.1007/s00401-013-1181-y

90. Mackenzie IR, Neumann M, Bigio EH, Cairns NJ, Alafuzoff I, Kril J, Kovacs GG, Ghetti B, Halliday G, Holm IE et al (2010) Nomenclature and nosology for neuropathologic subtypes of frontotemporal lobar degeneration: an update. Acta Neuropathol 119:1-4. doi:10.1007/s00401-009-0612-2

91. Mandal PK, Pettegrew JW, Masliah E, Hamilton RL, Mandal R (2006) Interaction between Abeta peptide and alpha synuclein: molecular mechanisms in overlapping pathology of Alzheimer's and Parkinson's in dementia with Lewy body disease. Neurochem Res 31:1153-1162. doi:10.1007/ s11064-006-9140-9

92. Masliah E, Rockenstein E, Veinbergs I, Sagara Y, Mallory M, Hashimoto M, Mucke L (2001) beta-amyloid peptides enhance alpha-synuclein accumulation and neuronal deficits in a transgenic mouse model linking Alzheimer's disease and Parkinson's disease. Proc Natl Acad Sci USA 98:12245-12250. doi:10.1073/pnas.211412398

93. Masters CL, Simms G, Weinman NA, Multhaup G, McDonald BL, Beyreuther K (1985) Amyloid plaque core protein in Alzheimer disease and Down syndrome. Proc Natl Acad Sci USA 82:4245-4249

94. Masuda-Suzukake M, Nonaka T (2014) Pathological alphasynuclein propagates through neural networks. Acta Neuropathol Comm 2:88. doi:10.1186/s40478-014-0088-8

95. McAleese KE, Walker L, Erskine D, Thomas AJ, McKeith IG, Attems J (2016) TDP-43 pathology in Alzheimer's disease, dementia with Lewy bodies and ageing. Brain Pathol. doi:10.1111/bpa.12424 (in press)

96. McKeith IG, Galasko D, Kosaka K, Perry EK, Dickson DW, Hansen LA, Salmon DP, Lowe J, Mirra SS, Byrne EJ et al (1996) Consensus guidelines for the clinical and pathologic diagnosis of dementia with Lewy bodies (DLB): report of the consortium on DLB international workshop. Neurology 47:1113-1124

97. Micheva KD, Smith SJ (2007) Array tomography: a new tool for imaging the molecular architecture and ultrastructure of neural circuits. Neuron 55:25-36. doi:10.1016/j.neuron.2007.06.014

98. Mirra SS, Heyman A, McKeel D, Sumi SM, Crain BJ, Brownlee LM, Vogel FS, Hughes JP, van Belle G, Berg L (1991) The Consortium to Establish a Registry for Alzheimer's Disease (CERAD). Part II. Standardization of the neuropathologic assessment of Alzheimer's disease. Neurology 41:479-486

99. Molliex A, Temirov J, Lee J, Coughlin M, Kanagaraj AP (2015) Phase separation by low complexity domains promotes stress granule assembly and drives pathological fibrillization. Cell 163:123-133

100. Moreno F, Rabinovici GD, Karydas A, Miller Z, Hsu SC, Legati A, Fong J, Schonhaut D, Esselmann H, Watson C et al (2015) A novel mutation P112H in the TARDBP gene associated with frontotemporal lobar degeneration without motor neuron disease and abundant neuritic amyloid plaques. Acta Neuropathol Commun 3:19. doi:10.1186/s40478-015-0190-6 
101. Mori K, Weng SM, Arzberger T, May S, Rentzsch K, Kremmer E, Schmid B, Kretzschmar HA, Cruts M, Van Broeckhoven $\mathrm{C}$ et al (2013) The C9orf72 GGGGCC repeat is translated into aggregating dipeptide-repeat proteins in FTLD/ ALS. Science 339:1335-1338. doi:10.1126/science.1232927

102. Morimoto S, Hatsuta H, Kokubo Y, Nakano Y, Hasegawa M, Yoneda M, Hirokawa Y, Kuzuhara S, Shiraishi T, Murayama S (2017) Unusual tau pathology of the cerebellum in patients with amyotrophic lateral sclerosis/parkinsonism-dementia complex from the kii peninsula, Japan. Brain Pathol. doi:10.1111/bpa.12500 (Epub ahead of print)

103. Morris M, Koyama A, Masliah E, Mucke L (2011) Tau reduction does not prevent motor deficits in two mouse models of Parkinson's disease. PLoS One 6:e29257. doi:10.1371/journal.pone.0029257

104. Moussaud S, Jones DR, Moussaud-Lamodiere EL, Delenclos M, Ross OA, McLean PJ (2014) Alpha-synuclein and tau: teammates in neurodegeneration? Mol Neurodegener 9:43. doi:10.1186/1750-1326-9-43

105. Nelson PT, Jicha GA, Kryscio RJ, Abner EL, Schmitt FA, Cooper G, Xu LO, Smith CD, Markesbery WR (2010) Low sensitivity in clinical diagnoses of dementia with Lewy bodies. J Neurol 257:359-366. doi:10.1007/s00415-009-5324-y

106. Neumann M, Kwong LK, Truax AC, Vanmassenhove B, Kretzschmar HA, Van Deerlin VM, Clark CM, Grossman M, Miller BL, Trojanowski JQ et al (2007) TDP-43-positive white matter pathology in frontotemporal lobar degeneration with ubiquitin-positive inclusions. J Neuropathol Exp Neurol 66:177-183. doi:10.1097/01.jnen.0000248554.45456.58

107. Neumann M, Sampathu DM, Kwong LK, Truax AC, Micsenyi MC, Chou TT, Bruce J, Schuck T, Grossman M, Clark $\mathrm{CM}$ et al (2006) Ubiquitinated TDP-43 in frontotemporal lobar degeneration and amyotrophic lateral sclerosis. Science 314:130-133

108. Oddo S, Billings L, Kesslak JP, Cribbs DH, LaFerla FM (2004) Abeta immunotherapy leads to clearance of early, but not late, hyperphosphorylated tau aggregates via the proteasome. Neuron 43:321-332. doi:10.1016/j.neuron.2004.07.003

109. Ono K, Takahashi R, Ikeda T, Yamada M (2012) Cross seeding effects of amyloid protein and synuclein. J Neurochem 122:883-890. doi:10.1111/j.1471-4159.2012.07847.x

110. Pastor P, Moreno F, Clarimon J, Ruiz A, Combarros O, Calero M, Lopez de Munain A, Bullido MJ, de Pancorbo MM, Carro E et al (2015) MAPT H1 haplotype is associated with lateonset Alzheimer's disease risk in APOE epsilon 4 noncarriers: results from the Dementia Genetics Spanish Consortium. J Alzheimers Dis 49:343-352. doi:10.3233/JAD-150555

111. Peelaerts W, Bousset L, Van der Perren A, Moskalyuk A, Pulizzi R, Giugliano M, Van den Haute C, Melki R, Baekelandt V (2015) alpha-Synuclein strains cause distinct synucleinopathies after local and systemic administration. Nature 522:340-344. doi:10.1038/nature14547

112. Pesiridis GS, Tripathy K, Tanik S, Trojanowski JQ, Lee VM (2011) A "two-hit" hypothesis for inclusion formation by carboxyl-terminal fragments of TDP-43 protein linked to RNA depletion and impaired microtubule-dependent transport. J Biol Chem 286:18845-18855. doi:10.1074/jbc.M111.231118

113. Polymeropoulos MH, Lavedan C, Leroy E, Ide SE, Dehejia A, Dutra A, Pike B, Root H, Rubenstein J, Boyer R et al (1997) Mutation in the alpha-synuclein gene identified in families with Parkinson's disease. Science 276:2045-2047

114. Pooler AM, Polydoro M, Maury EA, Nicholls SB, Reddy SM, Wegmann S, William C, Saqran L, Cagsal-Getkin O, Pitstick R et al (2015) Amyloid accelerates tau propagation and toxicity in a model of early Alzheimer's disease. Acta Neuropathol Commun 3:14. doi:10.1186/s40478-015-0199-x
115. Renton AE, Chiò A, Traynor BJ (2014) State of play in amyotrophic lateral sclerosis genetics. Nat Neurosci 17:17-23

116. Renton AE, Majounie E, Waite A, Simon-Sanchez J, Rollinson S, Gibbs JR, Schymick JC, Laaksovirta H, van Swieten JC, Myllykangas L et al (2011) A hexanucleotide repeat expansion in C9ORF72 is the cause of chromosome 9p21-linked ALSFTD. Neuron 72:257-268. doi:10.1016/j.neuron.2011.09.010

117. Rijal Upadhaya A, Kosterin I, Kumar S, Von Arnim C, Yamaguchi H, Fändrich M, Walter J, Thal DR (2014) Biochemical stages of amyloid $\beta$-peptide aggregation and accumulation in the human brain and their association with symptomatic and pathologically-preclinical Alzheimer's disease. Brain 137:887-903

118. Rijal Upadhaya A, Scheibe F, Kosterin I, Abramowski D, Gerth J, Kumar S, Liebau S, Yamaguchi H, Walter J, Staufenbiel M et al (2013) The type of Abeta-related neuronal degeneration differs between amyloid precursor protein (APP23) and amyloid beta-peptide (APP48) transgenic mice. Acta Neuropathol Commun 1:77. doi:10.1186/2051-5960-1-77

119. Roberson ED, Scearce-Levie K, Palop JJ, Yan F, Cheng IH, Wu T, Gerstein H, Yu GQ, Mucke L (2007) Reducing endogenous tau ameliorates amyloid beta-induced deficits in an Alzheimer's disease mouse model. Science 316:750-754

120. Rogaev EI, Sherrington R, Rogaeva EA, Levesque G, Ikeda M, Liang Y, Chi H, Lin C, Holman K, Tsuda T et al (1995) Familial Alzheimer's disease in kindreds with missense mutations in a gene on chromosome 1 related to the Alzheimer's disease type 3 gene. Nature 376:775-778

121. Schröder R, Watts GD, Mehta SG, Evert BO, Broich P, Fliessbach K, Pauls K, Hans VH, Kimonis V, Thal DR (2005) Mutant valosin-containing protein causes a novel type of frontotemporal dementia. Ann Neurol 57:457-461

122. Sengupta U, Guerrero-Muñoz MJ, Castillo-Carranza DL, Lasagna-Reeves CA, Gerson JE, Paulucci-Holthauzen AA, Krishnamurthy S, Farhed M, Jackson GR, Kayed R (2015) Pathological interface between oligomeric alpha-synuclein and tau in synucleinopathies. Biol Psychiat 78:672-683. doi:10.1016/j. biopsych.2014.12.019

123. Sepulcre J, Schultz AP, Sabuncu M, Gomez-Isla T, Chhatwal J, Becker A, Sperling R, Johnson KA (2016) In vivo tau, amyloid, and gray matter profiles in the aging brain. J Neurosci 36:73647374. doi:10.1523/JNEUROSCI.0639-16.2016

124. Shipton OA, Leitz JR, Dworzak J, Acton CE, Tunbridge EM, Denk F, Dawson HN, Vitek MP, Wade-Martins R, Paulsen O et al (2011) Tau protein is required for amyloid \{beta $\}$-induced impairment of hippocampal long-term potentiation. J Neurosci 31:1688-1692. doi:10.1523/JNEUROSCI.2610-10.2011

125. Sieczkowski E, Milenkovic I, Venkataramani V, Giera R, Strobel T, Hoftberger R, Liberski PP, Auff E, Wirths O, Bayer TA et al (2015) I716F AbetaPP mutation associates with the deposition of oligomeric pyroglutamate amyloid-beta and alpha-Synucleinopathy with Lewy bodies. J Alzheimers Dis 44:103-114. doi:10.3233/JAD-141524

126. Singleton AB, Farrer M, Johnson J, Singleton A, Hague S, Kachergus J, Hulihan M, Peuralinna T, Dutra A, Nussbaum R et al (2003) alpha-Synuclein locus triplication causes Parkinson's disease. Science 302:841. doi:10.1126/science.1090278

127. Spinelli KJ, Taylor JK, Osterberg VR (2014) Presynaptic alpha-synuclein aggregation in a mouse model of Parkinson's disease. J Neurosci 34:2037-2050. doi:10.1523/ JNEUROSCI.2581-13.2014

128. Spires-Jones TL, Hyman BT (2014) The intersection of amyloid beta and tau at synapses in Alzheimer's disease. Neuron 82:756-771. doi:10.1016/j.neuron.2014.05.004

129. Sreedharan J, Blair IP, Tripathi VB, Hu X, Vance C, Rogelj B, Ackerley S, Durnall JC, Williams KL, Buratti E et al (2008) 
TDP-43 mutations in familial and sporadic amyotrophic lateral sclerosis. Science 319:1668-1672

130. St George-Hyslop P, Haines J, Rogaev E, Mortilla M, Vaula G, Pericak-Vance M, Foncin JF, Montesi M, Bruni A, Sorbi S et al (1992) Genetic evidence for a novel familial Alzheimer's disease locus on chromosome 14. Nat Genet 2:330-334

131. St. George-Hyslop PH, Tanzi RE, Polinsky RJ, Haines JL, Nee L, Watkins PC, Myers RH, Feldman RG, Pollen D, Drachman $\mathrm{D}$ et al (1987) The genetic defect causing familial Alzheimer's disease maps on chromosome 21. Science 235:885-890

132. Stefansson H, Helgason A, Thorleifsson G, Steinthorsdottir V, Masson G, Barnard J, Baker A, Jonasdottir A, Ingason A, Gudnadottir VG et al (2005) A common inversion under selection in Europeans. Nat Genet 37:129-137. doi:10.1038/ng1508

133. Stöhr J, Condello C, Watts JC, Bloch L, Oehler A, Nick M, DeArmond SJ, Giles K, DeGrado WF, Prusiner SB (2014) Distinct synthetic $A \beta$ prion strains producing different amyloid deposits in bigenic mice. Proc Natl Acad Sci USA 111:1032910334. doi:10.1073/pnas.1408968111

134. Sturchler-Pierrat C, Abramowski D, Duke M, Wiederhold KH, Mistl C, Rothacher S, Ledermann B, Burki K, Frey P, Paganetti PA et al (1997) Two amyloid precursor protein transgenic mouse models with Alzheimer disease-like pathology. Proc Natl Acad Sci USA 94:13287-13292

135. Swirski M, Miners JS, de Silva R, Lashley T, Ling H, Holton J, Revesz T, Love S (2014) Evaluating the relationship between amyloid-beta and alpha-synuclein phosphorylated at Ser129 in dementia with Lewy bodies and Parkinson's disease. Alzheimers Res Ther 6:77. doi:10.1186/s13195-014-0077-y

136. Takahashi RH, Capetillo-Zarate E, Lin MT, Milner TA, Gouras GK (2010) Co-occurrence of Alzheimer's disease $\beta$-amyloid and tau pathologies at synapses. Neurobiol Aging 31:11451152. doi:10.1016/j.neurobiolaging.2008.07.021

137. Tanzi RE, Gusella JF, Watkins PC, Bruns GA, St. George-Hyslop P, Van Keuren ML, Patterson D, Pagan S, Kurnit DM, Neve RL (1987) Amyloid beta protein gene: cDNA, mRNA distribution, and genetic linkage near the Alzheimer locus. Science 235:880-884

138. Terry RD, Peck A, DeTeresa R, Schechter R, Horoupian DS (1981) Some morphometric aspects of the brain in senile dementia of the Alzheimer type. Ann Neurol 10:184-192

139. Thal DR, Del Tredici K, Ludolph AC, Hoozemans JJ, Rozemuller AJ, Braak H, Knippschild U (2011) Stages of granulovacuolar degeneration: their relation to Alzheimer's disease and chronic stress response. Acta Neuropathol 122:577-589. doi:10.1007/s00401-011-0871-6

140. Thal DR, Fandrich M (2015) Protein aggregation in Alzheimer's disease: abeta and tau and their potential roles in the pathogenesis of AD. Acta Neuropathol 129:163-165. doi:10.1007/ s00401-015-1387-2

141. Thal DR, Ghebremedhin E, Orantes M, Wiestler OD (2003) Vascular pathology in Alzheimer's disease: correlation of cerebral amyloid angiopathy and arteriosclerosis/lipohyalinosis with cognitive decline. J Neuropathol Exp Neurol 62:1287-1301

142. Thal DR, Griffin WS, Braak H (2008) Parenchymal and vascular Abeta-deposition and its effects on the degeneration of neurons and cognition in Alzheimer's disease. J Cell Mol Med $12: 1848-1862$

143. Thal DR, Rüb U, Orantes M, Braak H (2002) Phases of Abetadeposition in the human brain and its relevance for the development of AD. Neurology 58:1791-1800

144. Thal DR, Rüb U, Schultz C, Sassin I, Ghebremedhin E, Del Tredici K, Braak E, Braak H (2000) Sequence of Abeta-protein deposition in the human medial temporal lobe. J Neuropathol Exp Neurol 59:733-748
145. Thal DR, Schultz C, Botez G, Del Tredici K, Mrak RE, Griffin WS, Wiestler OD, Braak H, Ghebremedhin E (2005) The impact of argyrophilic grain disease on the development of dementia and its relationship to concurrent Alzheimer's diseaserelated pathology. Neuropathol Appl Neurobiol 31:270-279

146. Thal DR, von Arnim C, Griffin WS, Yamaguchi H, Mrak RE, Attems J, Rijal Upadhaya A (2013) Pathology of clinical and preclinical Alzheimer's disease. Eur Arch Psychiatry Clin Neurosci 263(Suppl 2):S137-S145. doi:10.1007/ s00406-013-0449-5

147. Thal DR, von Arnim CA, Griffin WS, Mrak RE, Walker L, Attems J, Arzberger T (2015) Frontotemporal lobar degeneration FTLD-tau: preclinical lesions, vascular, and Alzheimerrelated co-pathologies. J Neural Transm 122:1007-1018. doi:10.1007/s00702-014-1360-6

148. Thal DR, Zuchner S, Gierer S, Schulte C, Schols L, Schule R, Synofzik M (2015) Abnormal paraplegin expression in swollen neurites, tau- and alpha-Synuclein pathology in a case of hereditary spastic paraplegia SPG7 with an Ala510Val mutation. Int J Mol Sci 16:25050-25066. doi:10.3390/ijms161025050

149. Tsigelny IF, Crews L, Desplats P, Shaked GM (2008) Mechanisms of hybrid oligomer formation in the pathogenesis of combined Alzheimer's and Parkinson's diseases. PLoS One. doi:10.1371/journal.pone.0003135

150. Uchikado H, Lin WL, DeLucia MW, Dickson DW (2006) Alzheimer disease with amygdala Lewy bodies: a distinct form of alpha-synucleinopathy. J Neuropathol Exp Neurol 65:685-697. doi:10.1097/01.jnen.0000225908.90052.07

151. Um JW, Kaufman AC, Kostylev M, Heiss JK, Stagi M, Takahashi H, Kerrisk ME, Vortmeyer A, Wisniewski T, Koleske AJ et al (2013) Metabotropic glutamate receptor 5 is a coreceptor for Alzheimer abeta oligomer bound to cellular prion protein. Neuron 79:887-902. doi:10.1016/j.neuron.2013.06.036

152. Umeda T, Maekawa S, Kimura T, Takashima A, Tomiyama T, Mori H (2014) Neurofibrillary tangle formation by introducing wild-type human tau into APP transgenic mice. Acta Neuropathol 127:685-698. doi:10.1007/s00401-014-1259-1

153. Uryu K, Nakashima-Yasuda H, Forman MS, Kwong LK, Clark CM, Grossman M, Miller BL, Kretzschmar HA, Lee VM, Trojanowski JQ et al (2008) Concomitant TAR-DNAbinding protein 43 pathology is present in Alzheimer disease and corticobasal degeneration but not in other tauopathies. J Neuropathol Exp Neurol 67:555-564. doi:10.1097/ NEN.0b013e31817713b5

154. Volpicelli-Daley LA, Luk KC, Patel TP, Tanik SA, Riddle DM, Stieber A, Meaney DF, Trojanowski JQ, Lee VM (2011) Exogenous $\alpha$-synuclein fibrils induce Lewy body pathology leading to synaptic dysfunction and neuron death. Neuron 72:57-71

155. Wade-Martins R (2012) Genetics: the MAPT locus-a genetic paradigm in disease susceptibility. Nat Rev Neurol 8:477-478

156. Walker L, McAleese KE, Thomas AJ, Johnson M, Martin-Ruiz C, Parker C, Colloby SJ, Jellinger K, Attems J (2015) Neuropathologically mixed Alzheimer's and Lewy body disease: burden of pathological protein aggregates differs between clinical phenotypes. Acta Neuropathol 129:729-748. doi:10.1007/ s00401-015-1406-3

157. Walls KC, Ager RR, Vasilevko V, Cheng D, Medeiros R, LaFerla FM (2014) p-Tau immunotherapy reduces soluble and insoluble tau in aged 3xTg-AD mice. Neurosci Lett 575:96100. doi:10.1016/j.neulet.2014.05.047

158. Watts GD, Wymer J, Kovach MJ, Mehta SG, Mumm S, Darvish D, Pestronk A, Whyte MP, Kimonis VE (2004) Inclusion body myopathy associated with Paget disease of bone and frontotemporal dementia is caused by mutant valosin-containing protein. Nat Genet 36:377-381 
159. Watts JC, Condello C, Stöhr J, Oehler A, Lee J, DeArmond SJ, Lannfelt L, Ingelsson M, Giles K, Prusiner SB (2014) Serial propagation of distinct strains of $\mathrm{A} \beta$ prions from Alzheimer's disease patients. Proc Natl Acad Sci USA 111:10323-10328. doi:10.1073/pnas.1408900111

160. Wills J, Credle J, Haggerty T, Lee JH, Oaks AW, Sidhu A (2011) Tauopathic changes in the striatum of A53T alpha-synuclein mutant mouse model of Parkinson's disease. PLoS One 6:e17953. doi:10.1371/journal.pone.0017953

161. Wolfe MS, Xia W, Ostaszewski BL, Diehl TS, Kimberly WT, Selkoe DJ (1999) Two transmembrane aspartates in presenilin-1 required for presenilin endoproteolysis and gamma-secretase activity. Nature 398:513-517
162. Yang W, Strong MJ (2012) Widespread neuronal and glial hyperphosphorylated tau deposition in ALS with cognitive impairment. Amyotroph Lateral Scler 13:178-193. doi:10.3109 /17482968.2011.622405

163. Zempel H, Thies E, Mandelkow E, Mandelkow E-M (2010) A $\beta$ oligomers cause localized $\mathrm{Ca} 2+$ elevation, missorting of endogenous Tau into dendrites, Tau phosphorylation, and destruction of microtubules and spines. J Neurosci 30:11938-11950. doi:10.1523/jneurosci.2357-10.2010 